\title{
Intra-species structuring in the common shrew Sorex araneus (Lipotyphla: Soricidae) in European Russia: morphometric variability could give evidence of limitation of interpopulation migration
}

\author{
Nikolay A. Shchipanov*, Leonid L. Voyta, Anatoly V. Bobretsov \\ \& Inna F. Kuprianova
}

\begin{abstract}
The shape of the skull, mandible, and first lower molar (m1) in 10 geographical samples from four chromosomal races of two karyotypic groups were studied using geometric morphometrics. Discriminant analysis with cross-validation was used to test the accuracy of classifications of specimens using skull shape. The percentage of correct classifications attributed to race varied from $61.8 \%$ to $89.5 \%$ and ranged from $51.6 \%$ to $82.3 \%$ for geographical samples. The structuring between races, as measured with $Q_{s t}$ (this metric is analogous to $F_{s t}$, and the latter is used as a measure of genetic disparity between samples), was less than population-level structuring both within and between races. Variance between karyotypic groups in skull size, mandible, and molar shape was greater than between races. In skull shape, the variance was smaller as compared to the inter-racial level without larger "mountain" samples and greater when the entire set of samples was estimated. Interpopulation differences in all census characteristics were the most prominent. The magnitude of $Q_{s t}$ in interpopulation estimations was similar both among populations of the same race and among populations of different races. Lack of correlation of $Q_{s t}$ level with geographical distance between samples was found both in size and shape of the skull, mandible, and first lower molar. The significant difference between populations within a race was regarded as evidence of limitation of interpopulation migration. Each pair of geographic samples has a unique set of differentiating features. The stochastic variability of traits between the local samples, irrespective of race, is interpreted as evidence of genetic drift within partly isolated local populations. Diminishing differences between races could be a consequence of reabsorbing those stochastic morphological differences back into the metapopulations. The greater level of phenotypic differentiation between karyotypic groups compared to races is interpreted as a greater amount of time elapsed since the time of common ancestry.
\end{abstract}

KEY WORDS: chromosomal race, geometric morphometrics, interpopulation migration, intra-species structuring, Sorex araneus.

Nikolay A. Shchipanov [shchipa@mail.ru], A.N. Severtsov Institute of Ecology and Evolution of the Russian Academy of Sciences, Leninsky pr. 33, Moscow 119071, Russia; Leonid L. Voyta [leonid.voyta@zin.ru], Zoological Institute of the Russian Academy of Sciences. Universitetskaya emb. 1, Saint Petersburg 199034, Russia; Institute of Natural Resources, Ecology and Cryology of the Siberian Division of the Russian Academy of Sciences, Butina str. 26, Chita 672090,Russia; AnatolyV.Bobretsov [avbobr@mail.ru],Inna F.Kuprianova [inkupr@mail.ru], Pechora-Ilych State Nature Reserve, Laninoy str. 8, Yaksha Village 169436, Komi Republic, Russia.

\section{Внутривидовая структурированность обыкновенной бурозубки Sorex araneus (Lipotyphla: Soricidae) Европейской части России: морфометрическая изменчивость может свидетельствовать об ограничении межпопуляционной миграции}

\author{
Н.А. Щипанов, Л.Л. Войта, А.В. Бобрецов, И.Ф. Куприянова
}

РЕЗЮМЕ. Методами геометрической морфометрии изучали форму черепа, нижней челюсти и первого нижнего коренного зуба (m1) 10 географических выборок, принадлежащих 4 хромосомным расам двух кариотипических групп. Для выяснения точности классификации экземпляров по форме черепа использовали дискриминантный анализ с перестановочным тестом. Процент корректной классификации экземпляров по принадлежности к хромосомной расе варьировал в переделах 61.8$89.5 \%$, по принадлежности географической выборке - 51.6-82.3\%. Морфометрическая дистанция между расами, оцененная с помощью $Q_{s t}$ (аналог показателя $F_{s t}$, используемого как мера генетичес-

* Corresponding author 
кой неоднородности), была меньше чем между популяциями как одной расы, так и разных рас. Различие между кариотипическими группами по размерам черепа, нижней челюсти и форме моляра было больше, чем между расами. По форме черепа варьирование внутри рас, по сравнению с межрасовым, было меньше без учета более крупных «горных» выборок, или больше, с учетом этих выборок. Межпопуляционные различия всех рассмотренных характеристик выражены наиболее сильно. Величина $Q_{s t}$ в межпопуляционных сравнениях внутри одной расы и между популяциями разных рас сходна. Отмечено отсутствие корреляции величины $Q_{s t}$ с географической дистанцией между выборками как по размеру, так и по форме черепа, нижней челюсти и моляра. Значимое различие между популяциями внутри расы рассматривается как свидетельство ограничения межпопуляционной миграции. Каждая пара выборок имеет уникальные наборы дифференцирующих признаков. Случайное варьирование морфометрических характеристик среди локальных выборок, независимо от расы рассматривали как свидетельство действия генетического дрейфа в частично изолированных локальных популяциях. Уменьшение уровня различий между объединенными выборками рас является следствием объединения стохастических различий в общей выборке из метапопуляции. Более высокий уровень фенотипической дифференциации между кариотипическими группами по сравнению с межрасовым рассматривают как результат более давней дифференциации от общего предка.

КЛЮЧЕВЫЕ СЛОВА: хромосомная раса, геометрическая морфометрия, межпопуляционная миграция, внутривидовая структурированность, Sorex araneus.

\section{Introduction}

The common shrew Sorex araneus L., 1758 exhibits extraordinary karyotypic variability, and at least 72 chromosomal races are known (Wójcik et al., 2003a; White et al., 2010). A chromosomal race represents a group of populations with a unique inherited set of metacentrics inhabiting a contiguous area (Hausser et al., 1994). The races were clustered in karyotypic groups of various hierarchic statuses (Searle \& Wójcik, 1998; Orlov et al., 2004). In 1987, the International Sorex araneus Cytogenetic Committee (ISACC) was built for studying the biology of species related to raciation in the terminology of Searle (1993). Long-term multidisciplinary studies over a broad geographic area have contributed to our general understanding of the biology of species (Searle et al., 2008). However the genetic aspects have been the most studied issue, whereas the morphological aspect remains poorly understood. It was found that morphometric studies could reveal phylogenetic signals (Caumul \& Polly, 2005; Cardini \& Elton, 2008). One could expect similar phenotypic differentiation of the common shrew. However visible morphologic differences are often incongruent with genetic differentiation of Sorex araneus. Out of the full geographic distribution of the species, the number of morphologically different subspecies determined by different authors ranged from two to six (Gureev, 1979; Dolgov, 1985; Yudin, 1989); in the most recent checklist "Mammal Species of the World" subspecies were not detected at all (Hutterer, 2005). It should be noted also that the ranges of those morphological subspecies that have been described encompass several chromosomal races, sometimes from different karyotypic phylogroups. In some cases, a single karyotypic race has been subdivided into different morphological subspecies. For example, the inhabited range of the nominotypical subspecies $S$. a. araneus encompasses all of the
European part of the former USSR, the North Urals, and the northern part of West Siberia (Gureev, 1979), while at least 17 chromosomal races from three karyotypic groups are known from this area (Pavlova et al., 2006). On the contrary, large and significant differences in morphology were found between common shrews inhabiting the North and South Urals (Bolshakov et al., 1996); however, the same Serov race lives at both areas (Polyakov et al., 2000; Shchipanov \& Pavlova, 2013). A lack of correspondence of karyotypical races to differentiation into subspecies was found in Ukraine (Mishta, 2007). So, the remarkable karyotypic diversity of the species is not congruent to its morphological differentiation. Indeed, at least two cases of clear morphological divergence were found between races of different karyotypic groups (Chętnicki et al., 1996; Polyakov et al., 2002). Moska and Paśko (2006) found that though individuals of races from the same karyotypic group (Lęgunski Młyn and Popielno) do not clearly differ, canonical analysis and multidimensional scaling allow discrimination between hybrids and non-hybrids. Okulova et al. (2007) found that several races differed in a number of dimensions and proportions of the skull. However, most authors did not find correspondence between membership in a chromosomal race and morphometric characteristics (Searle \& Thorpe, 1987; Hausser, 1994; Meyer \& Searle, 1994; Wójcik et al., 2000; Banaszek et al., 2003). Wójcik et al. (2003b) found a significant correlation between morphometric variation and environmental heterogeneity, whereas differences between distinct Polish races were weak and insignificant (Wójcik et al., 2000). The leading role of biogeography in morphological variability of the common shrew was emphasized in Scandinavian (Sulkava et al., 1985) and British chromosomal races (Searle \& Thorpe, 1987, Meyer \& Searle, 1994).

One might suppose that the range of disagreement in various karyological and morphological studies is 
attributed to a range of differences in karyotypes of the races. The common shrew has a variable part of the karyotype, represented by chromosomal arms $g, h, i, k$, $m, n, o, p, q$, and $r$, and invariant autosomes $a f, b c, j l$, and $t u$, as well as the sex chromosomes XX (de) in the female and $\mathrm{X}(d e) \mathrm{Y} 1(s) \mathrm{Y} 2(d v)$ in the male (Searle et al., 1991). The arms in the variable part of the karyotype may produce a metacentric chromosome through Robertsonian fusions or be retained as acrocentrics. All of the studied hybrid zones between chromosomal races of Sorex araneus were considered tension zones (Searle \& Wójcik, 1998) in the terminology of Key (1968). The width of such hybrid zones is maintained by selection against heterozygotes (Barton \& Hewitt, 1985). In the common shrew simple heterozygotes cause marginal reductions in fitness, while complex heterozygotes, especially with large rings or long chains in meiosis, are substantially unfit (Searle, 1993; Searle \& Wójcik, 1998). In accordance with theoretical predictions, the width of the hybrid zones in the common shrew is related to the degree of difference in karyotypes of the hybridizing races and to the complexity of their meiotic alignment (Bulatova et al., 2011; Polyakov et al., 2011). However hierarchical analyses of morphological differentiation in 24 chromosomal races and two sibling species (Sorex antinorii Bonaparte and Sorex coronatus Millet) show that it does not appear to be closely linked to karyotypic diversity. It was found that in $S$. araneus, "structuring as measured by $F_{s t}$ is greatest at the population and karyotypic group levels $\langle\ldots\rangle$, and the weakest at the level of the karyotypic race" (Polly, 2007: 82). Differences between populations within a race are often larger than differences between populations of different races and sometimes between different species of the $S$. araneus group.

Not only morphological but also allozyme polymorphism are inconsistent with karyotypical diversity (Wójcik, 1991; Wójcik et al., 1996; Ratkiewicz et al., 2003). Also, large molecular variability within races was found in a number of studies (Lugon-Mouline et al., 2000; Ratkiewiz et al., 2002; Andersson, 2004). Both the level of complexity of hybrids and the type of chromosomes had no effect on genetic distance between races, as it was measured with using microsatellite alleles (Horn et al., 2012). Lack of correspondence of genetic differences that have been measured by various sorts of markers with racial differentiation might look like evidence of unlimited gene flow across the hybrid zones (Frykman et al., 1983; Frykman \& Bengtsson, 1984; Searle, 1985, Wójcik \& Wójcik, 1994; Ratkievicz et al., 2003). However, many hybrid zones were characterized by a lack of hybrids (Searle \& Wójcik, 1998). It means that they are bimodal (Bulatova et al., 2011) in the terminology of Jiggins \& Mallet (2000). According to Jiggins and Mallet (2000), bimodality is evidence of "a route to speciation" or is a witness of inhibition of gene flow between contacting forms. Also almost all authors show that intra-racial structuring is significant, and sometimes it is greater than interracial structuring (Lugon-Mouline et al., 2000; Ratkievicz et al., 2002; Horn et al., 2012). We suppose that the paradoxical results of estimations with using various kinds of frequency markers versus chromosomal diversity could be explained by a remarkable impediment of gene flow not only between races but also between populations within races.

In our present study, we focus on the interracial and interpopulation morphometric variability of the common shrew in north-eastern European Russia. The idea of the study is to analyze the variability of the skull, mandible, and molar in size and shape using voluminous samples collected in the course of regular monitoring of small mammal populations. The samples were collected from sites inhabited by pure races. The membership in a race was supported by karyological studies in all sampled areas. Although we can not analyze molecular diversity exactly in the studied samples, we could estimate results of the application of analogous statistics from geometric morphometric studies. The samples represent different populations of various chromosomal races from different geographic regions hence, various environments. Using methods of geometric morphometrics facilitates estimation of morphological distances between samples of the same race either between samples of different races as well as estimation of differences related to distances and geographic and environmental gradients. We suppose that variability in shape and size could reflect both indeterminate genetic variability and selection in partly isolated populations. In case of predominance of variability related to environmental heterogeneity, one may expect correlation of environmental gradients and a level of divergence between samples, whereas in the case of a leading role of indeterminate variability within partly isolated local populations, the morphological distances between samples should not be related to environmental gradients. We anticipate that a similar range of differences between populations of distinct races and between populations within races could indicate similar levels of limitation of interpopulation migration. A level of divergence is supposed to be estimated as $Q_{s t}$, which is analogous to $F_{s t}$ for quantitative data (see below).

\section{Material and methods}

A total of 634 individuals from 10 geographical samples of four chromosomal races (Serov, Manturovo, Pechora, Sok) of the common shrew were studied (Fig. 1, Appendix 1). All the samples were obtained from lowlands at altitudes ranging from 80 to $150 \mathrm{~m}$ above sea level except samples of the Serov race. Samples of the former race were collected from lowlands of the Yaksha (Se_V) and highlands of the Garevka (Se_F) and the Jany $(\overline{\mathrm{Se}} \mathrm{H})$ field stations of the Pechora-Ilych State Nature Reserve (Komi Republic, Russia). The Yaksha is situated in a so-called "plain region" of the reserve at about $180 \mathrm{~m}$ altitude. The Garevka is situated 


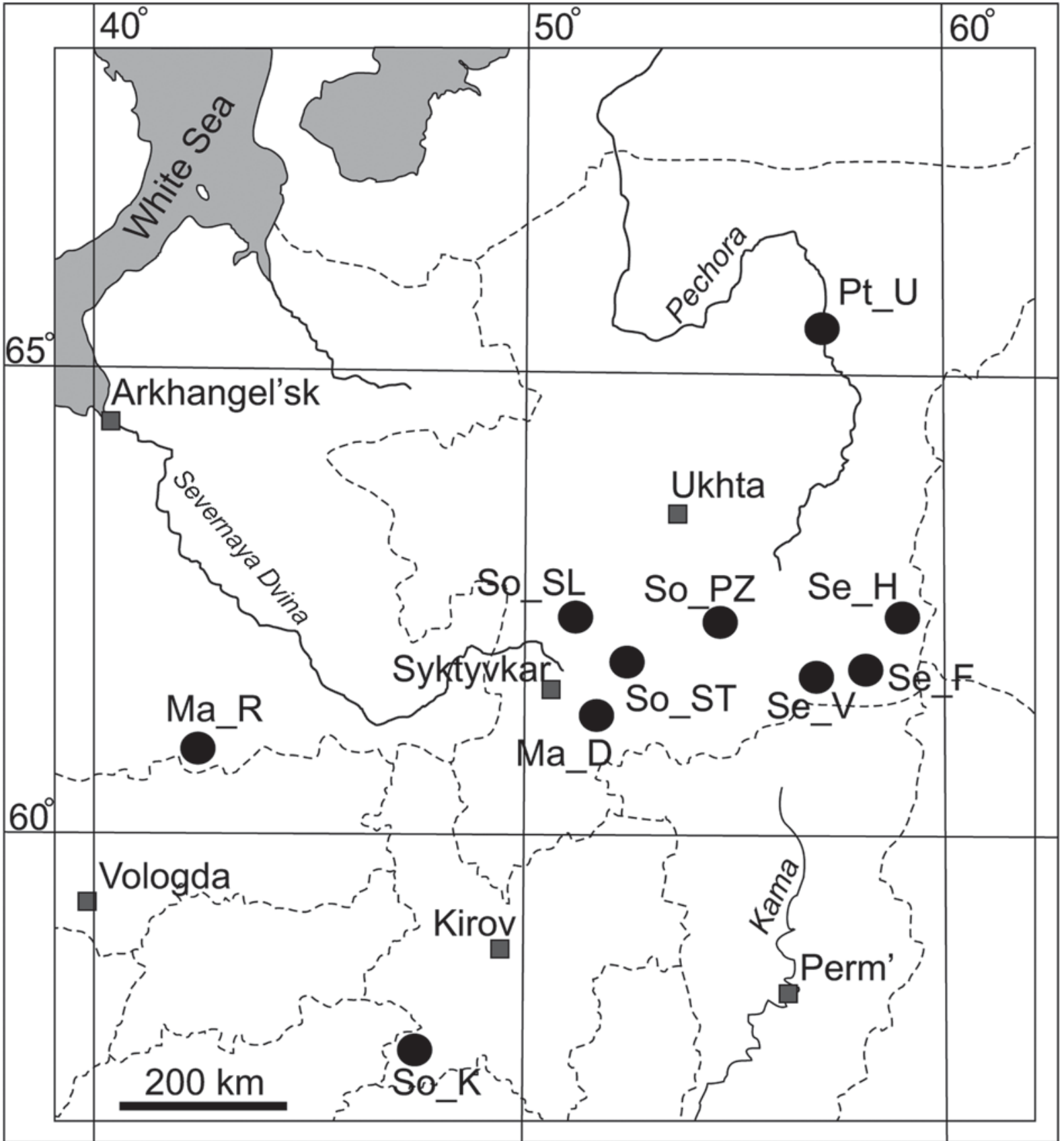

Figure 1. Location of samples used in the study. The karyotype of the samples and the localities of the sample are indicated by abbreviation (see Appendix 1).

at a foothill region at about $300 \mathrm{~m}$ altitude, and the Jany is situated at a hill at about $550 \mathrm{~m}$ above sea level. The membership in a race was identified under karyological studies at each of the localities (Bystrakova et al., 2007; Shchipanov et al., 2011; Shchipanov \& Pavlova, 2013). The Pechora race with $g i, h n, j l, k q, m o$, and $p r$ diagnostic chromosomes, and the Manturovo race with go, $h i$, $j l, k q, m n$, and $p r$ chromosomes represent the East European Karyotypic Group, EEKG (Orlov et al, 2004). The races have three different diagnostic metacentrics, $g o, h i$ and $m o$ in the Manturovo, versus gi, $h n$, and $m n$ in the Pechora race. The Sok race with chromosomes $g o, h n, i p, j l, k q$, and $m r$ and the Serov race with chromosomes go, hn, ip, jl, km, and $q r$ were assigned to the North European Karyotypic Group, NEKG (Searle \& Wójcik, 1998). The latter races differ by two chromosomes, $k q$ and $m r$ in the Sok vs $k m$ and $q r$ in the Serov race. The arising of the latter difference is supposedly a result of a simple WART occurring in the course of postglacial recolonization of the northern areas of Ural from some southern refuge (Polyakov et al., 2001).

The skulls were obtained either from individuals that proceeded with karyotyping or from individuals 

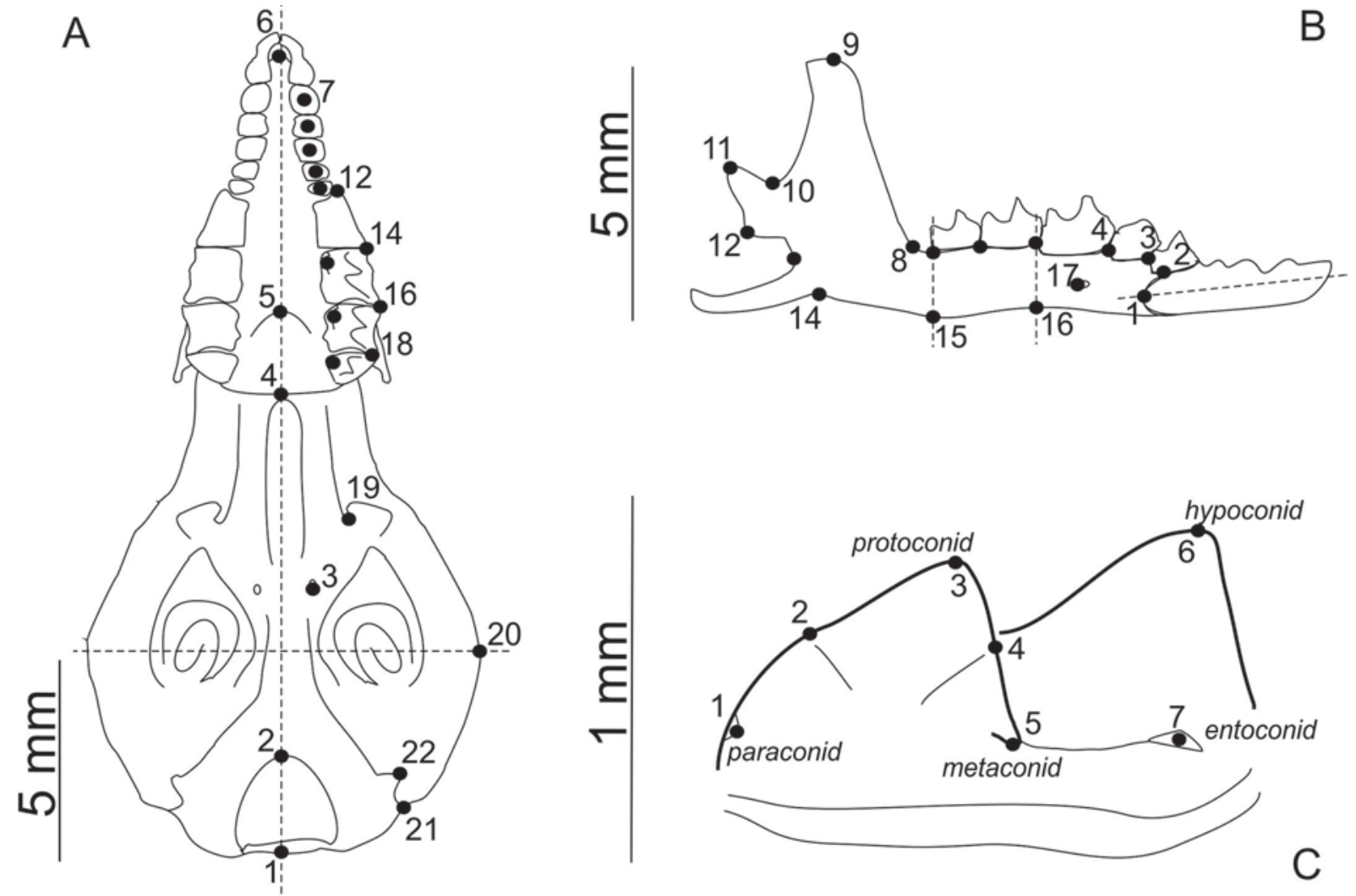

Figure 2. Geometric landmarks used in the study: landmarks of the skull in ventral view (A); landmarks of the mandible in lateral view (B); landmarks of the lower first molar in occlusal "functional view" (C). Scale bar is given left to the objects.

that had been caught in pitfalls in the course of monitoring small mammal populations. Although no formal animal use regulations exist in Russia, our work adhered to the recommendations of European Union Directive 2010/63/EU on the protection of animals for scientific purposes. Individuals for karyotyping were removed from live traps no more than in an hour after capture, after which they were placed in a separate cage with food and nest material and proceeded to the standard karyotyping protocol on the day of capture. Cranial specimens were deposited in the Museum of the Pechora-Ilych State Nature Reserve (Yaksha Village, Komi Republic, Russia) (see Appendix 1). Part of this collection has been analyzed in previous studies (Poroshin et al., 2010; Shchipanov et al., 2011; Bobretsov et al., 2012). The results of some of these studies provide a basis for comparison for the new data reported here.

Dramatic seasonal changes in the skeleton, particularly the skull, known as the Dehnel effect, are known to occur in soricines (Dehnel, 1949; Pucek, 1963, 1965, 1970; Churchfield, 1990; Hausser et al., 1990). Because of this, only young but fully grown shrews in their first calendar year of life, before winter reduction in bone and internal organ size, were included in this analysis. Age determination is straightforward in Sorex shrews. Individuals after wintering are at least $1.3-2$ times greater in weight and have a clearly visible weaned coat, especially notable in the tail (Churchfield, 1990). Age determination on skull specimens is also straightforward, based on tooth wear that removes colored tips of the teeth in overwintered individuals. All animals were caught in June-September, except the sample So_K ("Bolshaja Kokshaga" Nature Reserve, Sok race), which was collected in early October 2009. Sexual dimorphism is negligible in yearling shrews (Searle \& Thorpe, 1987). Here, we used mixed-gender samples.

The skull and mandible of each specimen were scanned in ventral and lateral views, respectively, using the Epson Perfection flatbed scanner with 2400 dpi resolution. The shape of each specimen was represented with two-dimensional Cartesian landmarks (Fig. 2). The first lower molar was photographed in "functional view" (Polly, 2003) on the Leica MZ 6 binocular microscope and landmarked five times, each was averaged to minimize orientation error (Polly, 2001, 2003, 2007), and landmarked three times for skull and mandible. The analysis was performed on mean values of these replicates. Each dataset (skull, mandible, m1) was aligned and analyzed separately (Voyta et al., 2013).

Centroid size was calculated as the square root of the sum of squared distances between the landmarks and the centroid (Bookstein, 1991). Following Polly (2007), we used centroid size as a character mathematically independent in shape, whereas linear measure- 


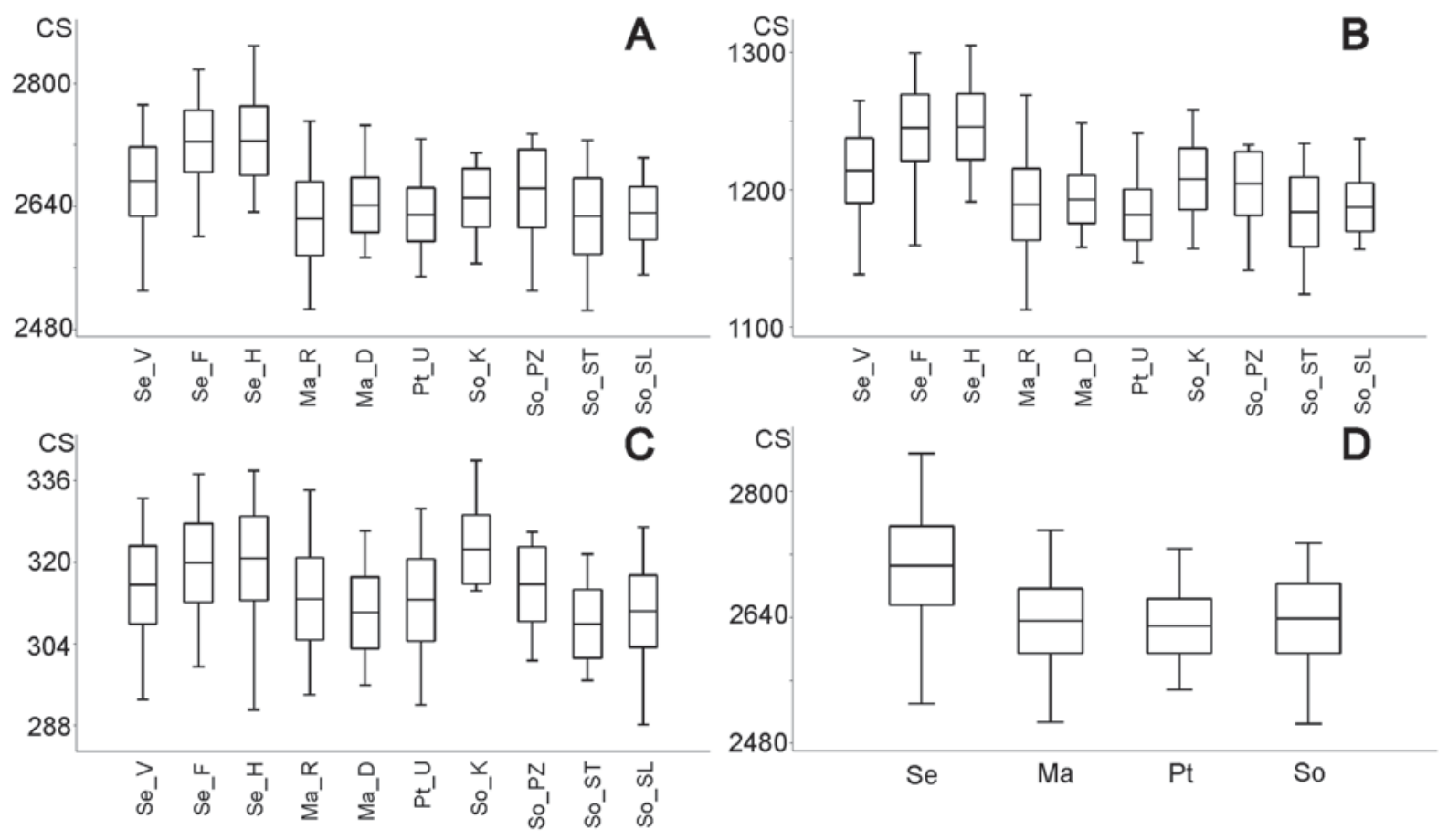

Figure 3. Box plot showing differences in the centroid size for skull (A), mandible (B), first lower molar (C) among geographical samples; and for skull (D) among four races. For abbreviations see Appendix 1. Whiskers - max - min; box standard deviation.

ments may be biased if they lie along a major axis of shape variation. Centroid size (CS), Procrustes coordinates (PrC), and relative warps (RW) were calculated with standard methods (Bookstein, 1991; Zelditch et al., 2004) in the program MorphoJ (Klingenberg, 2011). Landmarks were aligned using generalized Procrustes analysis (GPA) to remove differences in size, translation, and rotation. The aligned shapes were projected orthogonally into tangent space for further analysis (Rohlf \& Slice, 1990). The mean was subtracted from the GPA-superimposed landmarks to center their coordinate system, the covariance matrix of the residuals was calculated, and the residuals were projected onto the eigenvectors of the covariance matrix to obtain principal component scores that could be used as shape variables for subsequent statistical analysis. Differences in shape between individuals or populations were calculated as sum of the squared differences between scores for all principal components. Pairwise Procrustes distances ("all-to-all" and among samples' mean) were calculated based on the PrC of an object as the Euclidean distance in the program PAST (Hammer et al., 2001).

Structuring at the levels of population, race, karyological group, and species was assessed using $Q$-statistics. Actually, $Q_{s t}$ estimated the proportion of betweengroup to within-group variance, similar to Wright's (1951) assessment of genetic structuring with $F_{s t}$. However, the notation $Q_{s t}$ was suggested for $F_{s t}$ calculated from quantitative data to distinguish it from $F_{s t}$ calculated from molecular data (Spitze, 1993). One thousand jackknife iterations, in which a random member of the group was omitted, were performed. The jackknifed statistic $Q_{s t}$ was calculated using the formula:

$$
Q_{s t}=(n-1-k) S S B /(k-1)(S S W+S S B)
$$

where $S S B$ is the sum of squared distances between group means and the grand mean $S S W$ is the sum of squared distances between their group mean and individuals (from jackknifed samples), $n$ is the sample size, and $k$ is the number of groups (Polly, 2007). Following Polly, we estimated the standard error of $Q_{s t}$ as their standard deviation.

$Q_{s t}$ is analogous to $F_{s t}$, and the latter is used as a measure of genetic disparity between samples; we estimated isolation by distance by plotting pairwise $Q_{s t}$ against geographic distances. A linear regression line was used to illustrate the relationship.

Shapiro-Wilk test and Levine's test were used for testing the normality and homogeneity of each sample by CS. Statistical analyses were performed in PAST v. 2.04 and MorphoJ. One-way ANOVA was used to estimate ( $F$ - and Tukey's tests) size differences (log transformed CS) between geographical samples and races. MANOVA and CVA were used for shape (all RW) variation analysis of samples and races ( $\lambda$ Wilks, $F$-, and Hotelling's tests). Linear regression analysis was applied to assess clinal variation of size (CS) and shape (RW). Discriminant analysis with leave-out crossvalidation (jack-knife) was used for searching shape (PrC) differences between samples and races. To eliminate false assignment of significance by chance, Bonferroni correction was employed. 


\section{Results}

Shapiro-Wilk tests indicated a normal distribution of CS for each geographical sample $(p>0.05)$, and Levene's tests showed significant homogeneity of variances $(p>0.05)$ in each dataset (skull, mandible, and $\mathrm{m} 1)$.

\section{Geographic patterns of variation}

Size. One-way ANOVAs of mean CS showed significant differences among geographical samples for all datasets (skull: $F=55.04, p<0.001$; mandible: $F=$ 43.31, $p<0.001 ; \mathrm{ml}: F=23.42, p<0.001)$. All the $F$ values remained significant for $p<0.05$ after Bonferroni correction. The largest difference in size was the Serov race individuals ( $\mathrm{Se} F, \mathrm{Se} H$ ) sampled from foothills and highlands (see Appendix 2). The smallest size of the skull and mandible (Fig. 3) were found in samples of the Manturovo (Ma_R) and the Sok (So_ST) races. The biggest size of the $\overline{\mathrm{m}} 1$ was found in the $\overline{\text { most }}$ southern Sok race sample (So_K).

Regression analysis (ordinary least squares method) revealed high positive correlations with altitude in skull and mandible sizes in the entire set of samples: in skull, $r=0.732, p<0.001$, and in mandible, $r=0.719, p=$ 0.001 . In molar size, the correlation was not significant; $r=0.340, p=0.061$. In the present study, the largest shrews were found above 150 meters of altitude (Se Y, $\mathrm{Se}$ F, Se H). The sizes among those samples increased with altitude. The smallest individuals of the race were represented in the sample of the Serov race at lowlands (Se_Y), and the largest shrews were found in highland samples (Se_H). Significant variation was found in ANOVA among the Serov skull samples, $F=44.23, p<$ 0.0001 , mandible, $F=56.8, p<0.0001$, and molar, $F=$ 12.6, $p<0.0001$.

However, the only sample from the valley was significantly different $(p<0.0002)$, whereas "mountain" samples were not different between themselves at all ( $p$ $>0.99$ ) in Tukey's test. There were significant differences between mean CS of the Serov race and other races in the skull $(F=11.75, p<0.001)$ and mandible sizes $(F=11.56, p<0.001)$ but not in the size of $\mathrm{m} 1(F=$ $3.35, p=0.055)$. When we removed from the analyses of "mountain" samples of the race (Se_F and Se_H), all these differences disappeared. Thus, the differences were chiefly attributed to the altitude but not to the race.

No correlation was found with latitudes among our samples in skull $(r=-0.016, p>0.9)$. Even when significantly larger samples of the Serov race were omitted from analyses, a correlation remained insignificant $(r=-0.32, p>0.4)$. In mandible, the correlation was not significant under the presence of the Serov race samples $(r=-0.15, p>0.6)$; however, one could indicate a trend of diminishing in size among the other samples $(r=-0.68, p<0.09)$. No correlation was observed in molar size both among samples including and excluding the Serov race $(r=-0.42, p<0.20 ; r=$
$-0.60, p<0.15)$. Although we do not have sufficient data to assess the correlation between sizes and latitude accurately, it could be mentioned that the smallest samples were found among the Manturovo and the Sok races; however, the mean value of the northerly Pechora race sample was found to be slightly but insignificantly smaller as compared to the mean value of CS in the former races. We have to note that this is the unique sample of a most northern (among the census) race; thus, the result is tentative.

Because of the specifics of climate on the European part of northern Russia, the principal changes in environmental conditions are following in longitudinal directions. The severity of the climate is increasing eastwards. Hence, environmentally related differences could be expected in samples obtained from eastern and western sites of the area. Indeed, a significant positive correlation with longitude was found in skull size $(r=$ $0.66, p<0.04)$; however, the correlation was observed due to large specimens of the Serov race. When specimens of the race Serov were omitted, the correlation was low and insignificant $(r=0.26, p<0.55)$. And no correlation in mandible and molar size was found, irrespective of including analyses of the Serov race.

Shape. MANOVA of the skull and mandible relative warps revealed a significant overall difference among both the races (skull: $\lambda W i l k s=0.319, F=14.56$, $p<0.001$; mandible: $\lambda$ Wilks $=0.349, F=14.04, p<$ 0.001 ) and geographical samples (skull: $\lambda$ Wilks $=0.140$, $F=8.158, p<0.001$; mandible: $\lambda$ Wilks $=0.197, F=$ $6.61, p<0.001)$. However, these differences were obtained under highly overlapped polygons (Fig. 4A). It should be noted that the differences were revealed between the Manturovo and the Pechora races, but those races were represented by 2 and 1 samples, respectively. Skull shape in sample So_K does not differ from the So ST and So SL, and the mandible does not differ from the samples So PZ and So ST.

The Ma_R sample (Fig. 4B) is at the negative end of the first canonical variate (CV1) and shows differences in the skull shape that are associated with a relatively short rostrum (RW1), resulting in shortening of the antemolar row (between LM6-LM10), forward displacement of the posterior edge of the hard palate (LM4), and glenoid fossa (LM19); it also shows a more elongated brain case through the caudal displacement of the back of the cranium (LM 1 and LM21). The opposite characteristics of skull shape are found in the Serov race samples in the positive end of CV1 (Fig. 4B). Along CV2, differences were related to changes in the width of the rostral part. In the negative area of CV2, the deviations were expressed in the medial displacement of the antemolar row (LM7-LM11) and lateral displacement of the midline of the hard palate (LM 4 and LM5), with the wider brain case (LM20) (Fig. 5).

The shape of $\mathrm{m} 1$ was significantly different between the races $(\lambda W i l k s=0.540, F=14.20, p<0.001)$ and samples $(\lambda$ Wilks $=0.308, F=8.796, p<0.001)$. 


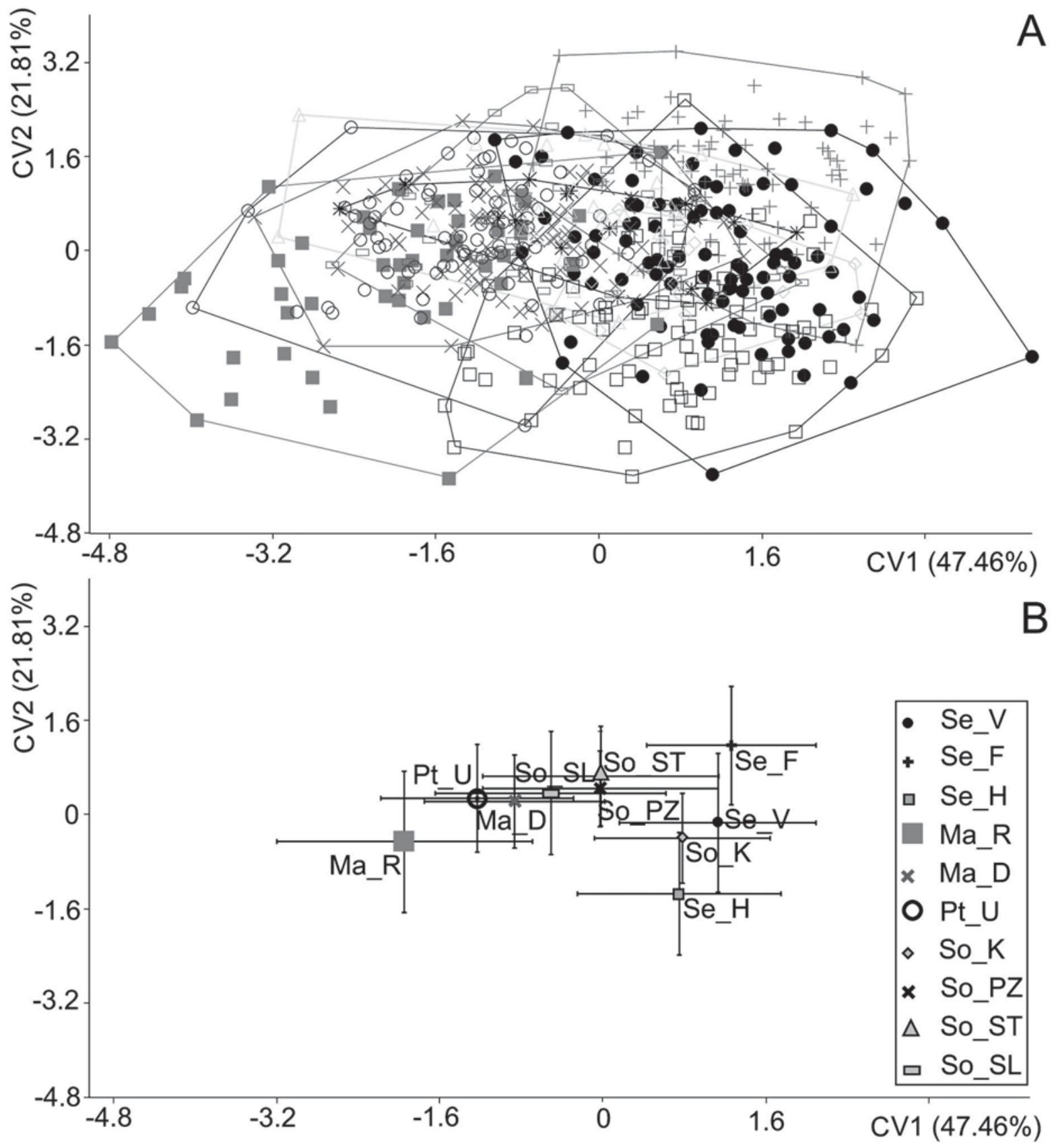

Figure 4. Scatterplot of canonical variates (CV1, CV2) of the skull: showing a convex hull around geographical samples (A) and the means of those groups with confidence intervals (standard deviation) (B). For abbreviations see Appendix 1.

Hotelling's test revealed significant differences between all pairs of races (except for the Manturovo and Pechora races, after Bonferroni correction, $p=0.075$ ), as well as in the majority of the pairs of samples, irrespective of race (Appendix 3).

Clinal variations of shape and size. Negative correlation between mandible shape (RW1) and altitude ( $r$ $=-0.824, p<0.001)$ was found, and the correlation resulted from the allometric effect. The allometric ef- fect related to altitude (CS vs RW1; $r=-0.644, p=$ 0.029 ) was found in the mandible shape (Fig. 6), chiefly due to the Serov race, which has a more caudal position of the coronoid process and large size sampled from the highlands ( $\mathrm{Se} \mathrm{F}$ and $\mathrm{Se} \mathrm{H}$ ). Positive correlation between RW1 in $\mathrm{m} 1$ and altitude was found $(r=0.749, p$ $=0.012)$. The highland samples of the Serov race are elongated in the anteroposterior direction of $\mathrm{m} 1$. The samples Se_F and Se_H were excluded from clinal variation analysis to minimize their influence on our 

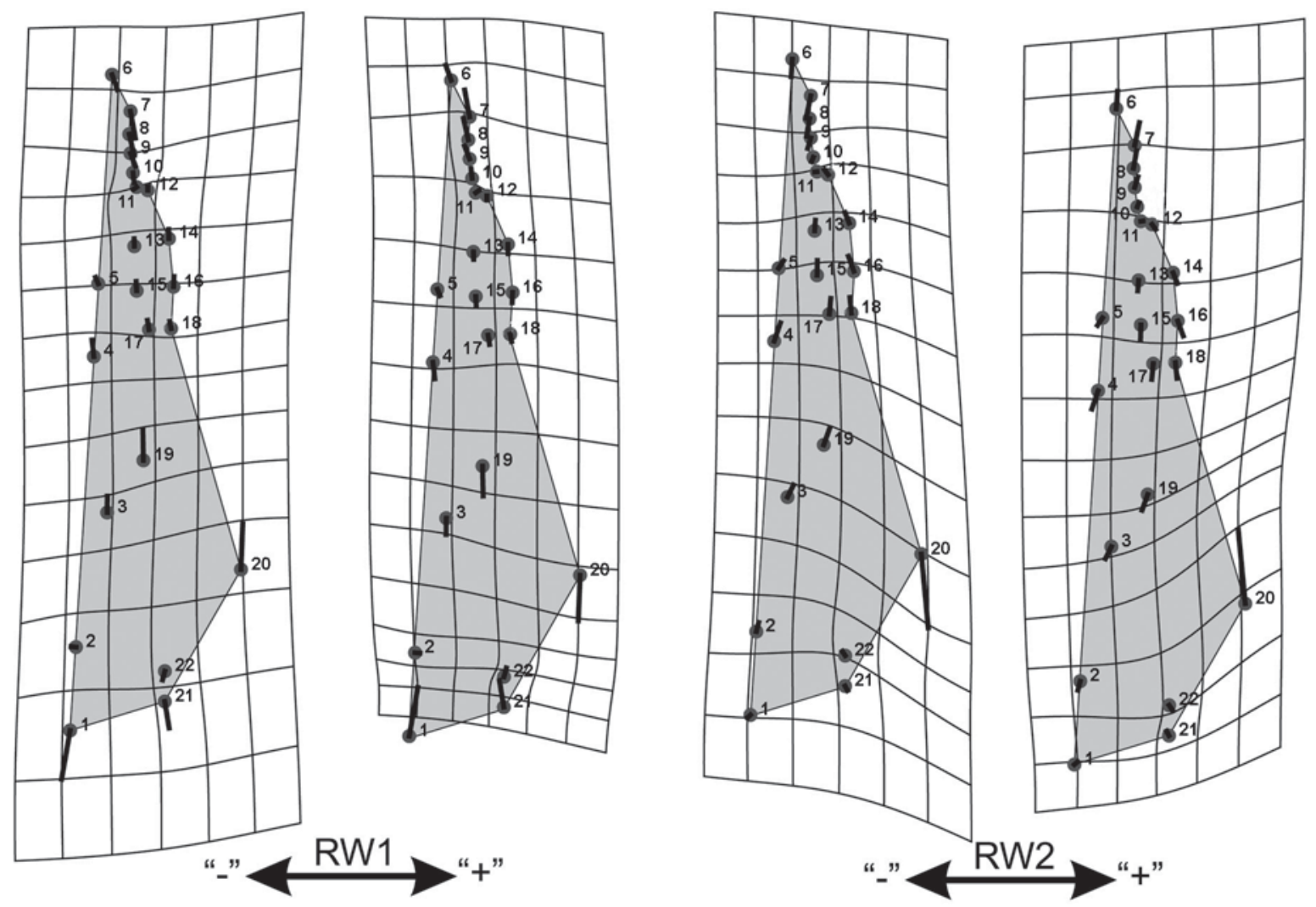

Figure 5. Transformation grids visualize shape deformation relative to the mean (regular grid, not shown) at the negative and positive extremes of the relative warps axes (RW1 and RW2).

results. As a result, clinal variation associated with latitude as well as differences in shape between the western and eastern samples was not found.

Interracial and interpopulation variability. Discriminant analysis of the Procrustes coordinates shows percentage of individuals correctly assigned to a race or to a sample and percentage of individuals indicated as members of a race or a sample within another race or sample. When membership in a race is more relevant one could expect more accurate classification for discrimination of races. In fact discriminant analysis revealed similar classification accuracy for discrimination of races (Tab. 1) and samples (Tab. 2). The percentage of correct classification of races ranged from 38.2 to $66.0 \%$, whereas the accuracy in the samples ranged from 47.4 to $82.3 \%$. Thus, the rate of correct classification is dependent on the peculiar samples involved in analyses.

The analysis revealed that each pair of races has their own specific differentiating features. For example, the Serov race differs from the Manturovo race in skull proportions and, namely, by the common position of LM 1 and LM19. Also, each pair of samples has a specific set of differentiating traits that are not suitable for discrimination between the races. The differences between $\mathrm{Se}$ V and Ma D by skull shape were associated with the position of the anterior palatine edge (LM 5 ) and the width of the brain case (LM20); however, those features were not significant in differentiating the Serov and Manturovo races (Fig. 7).

Morphological structuring with respect to karyotype differences. Structuring in morphology was estimated as $Q$-statistics. The greater the value of $Q_{s t}$ is, the greater the structuring is. $Q_{s t}$ was measured at four hierarchical levels: between populations of the same race, between population of different races, between different races, and between two karyotypic groups. In the analyses, $Q_{s t}$ showed a relative level of differentiation between groups as compared to variability within. We found high variations of the characters in our study (Tab. 3). Those variations were borne by extremely different samples of the Serov race from foothills and mountains against the lowland sample of the race (Fig. 3, see Se_F and Se_H). For example, skull size $Q_{\text {st }}$ of the lowland sample, as it measured against the consolidated "mountain" sample was $Q_{\text {st }}=0.77$ between the lowland Serov sample Se_V and Se_F, and $Q_{s t}$ equaled 0.56 between $\mathrm{Se} \_\mathrm{V}$ and $\overline{\mathrm{Se}} \mathrm{H}$. Note that the difference in skull size was extremely small between two "mountain" samples of the race: $Q_{s t}=0.003$ between Se_F and 

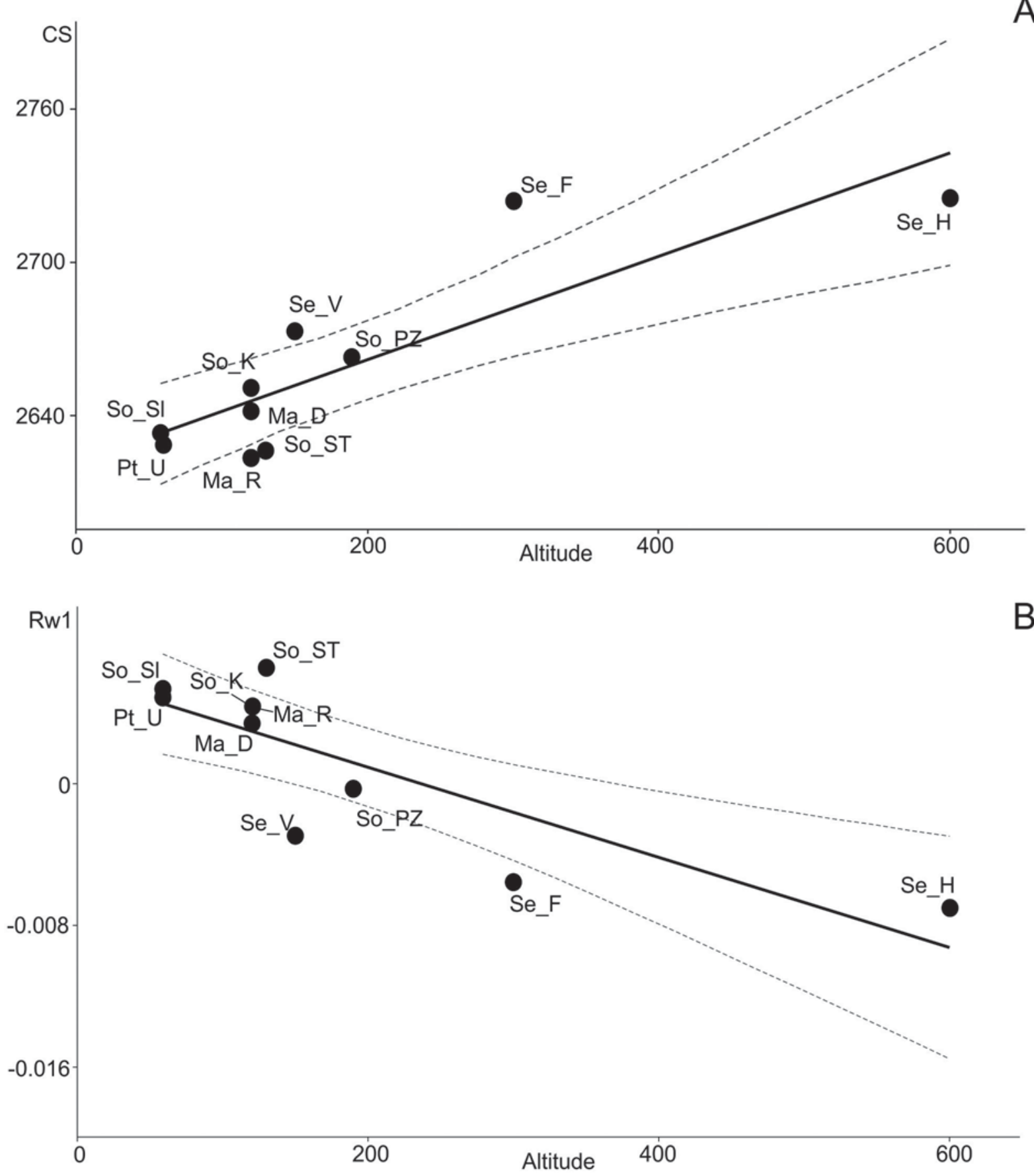

Figure 6. Linear regression of skull centroid size (CS) onto altitude (horizontal axis) (A); and linear regression of the first relative warp (PC1; mandible) onto altitude (B), with 95\% confidence bands. For abbreviations see Appendix 1.

Se H. Obviously, notably, a distinct race, Serov, could produce significant distortion in our estimations. Therefore, we estimated $Q_{s t}$ in sets of samples, including Serov race and excluding Serov race, and gave similar estimations from Polly (2007) in order to have a scale for comparisons. As a result, we found that divergence in the shape is less as compared to centroid size, except of the molar shape in the case of interracial comparison.
Similar to Polly (2007), we have found greater structuring between populations of the same race as compared to the structuring between the races. Also, the greatest structuring between karyotypic groups was found in the skull size and in the molar shape. Skull shape and mandible shape were less structured both between the races and between karyotypic groups and more structured between the populations. 
Table 1. Result of discriminant function analysis. Percentage of specimens referred correctly to races by skull shape after leave-one-out procedure. Percentage of correct classifications are given in bold.

\begin{tabular}{|l|c|c|c|c|}
\hline & Serov & Manturovo & Pechora & Sok \\
\hline Serov & $\mathbf{6 4 . 8}$ & 11.4 & 13.4 & 10.3 \\
\hline Manturovo & 10.3 & $\mathbf{6 6 . 0}$ & 10.9 & 12.8 \\
\hline Pechora & 11.5 & 20.5 & $\mathbf{6 0 . 3}$ & 7.7 \\
\hline Sok & 47.3 & 2.7 & 11.8 & $\mathbf{3 8 . 2}$ \\
\hline
\end{tabular}

Table 2. Result of discriminant function analysis. Percentage of specimens referred correctly to geographical samples by skull shape after leave-one-out procedure. Percentage of correct classifications are given in bold.

\begin{tabular}{|c|c|c|c|c|c|c|c|c|c|c|}
\hline & Se_V & Se_F & Se_H & Ma_R & Ma_D & Pt_U & So_K & So_PZ & So_ST & So_SL \\
\hline Se_V & $\mathbf{5 3 . 3}$ & 16.2 & 4.8 & 3.8 & 2.9 & 6.7 & 2.9 & 2.9 & 3.8 & 2.9 \\
\hline Se_F & 13.5 & $\mathbf{5 7 . 3}$ & 10.1 & 2.2 & 3.4 & 4.5 & 5.6 & 0.0 & 1.1 & 2.2 \\
\hline Se_H & 10.4 & 5.2 & $\mathbf{6 2 . 5}$ & 8.3 & 3.1 & 3.1 & 2.1 & 1.0 & 3.1 & 1.0 \\
\hline Ma_R & 1.8 & 3.6 & 9.1 & $\mathbf{5 8 . 2}$ & 12.7 & 3.6 & 3.6 & 1.8 & 3.6 & 1.8 \\
\hline Ma_D & 2.0 & 4.0 & 5.0 & 13.9 & $\mathbf{4 9 . 5}$ & 9.9 & 2.0 & 8.9 & 4.0 & 1.0 \\
\hline Pt_U & 7.7 & 3.8 & 0.0 & 6.4 & 15.4 & $\mathbf{4 7 . 4}$ & 1.3 & 1.3 & 11.5 & 5.1 \\
\hline So_K & 10.5 & 0.0 & 0.0 & 5.3 & 0.0 & 0.0 & $\mathbf{5 7 . 9}$ & 15.8 & 5.3 & 5.3 \\
\hline So_PZ & 0.0 & 0.0 & 0.0 & 0.0 & 0.0 & 0.0 & 22.2 & $\mathbf{7 2 . 2}$ & 5.6 & 0.0 \\
\hline So_ST & 0.0 & 6.5 & 0.0 & 3.2 & 0.0 & 3.2 & 6.5 & 9.7 & $\mathbf{5 1 . 6}$ & 19,4 \\
\hline So_SL & 0.0 & 0.0 & 0.0 & 0.0 & 0.0 & 0.0 & 0.0 & 0.0 & 0.0 & $\mathbf{8 2 . 3}$ \\
\hline
\end{tabular}

Se

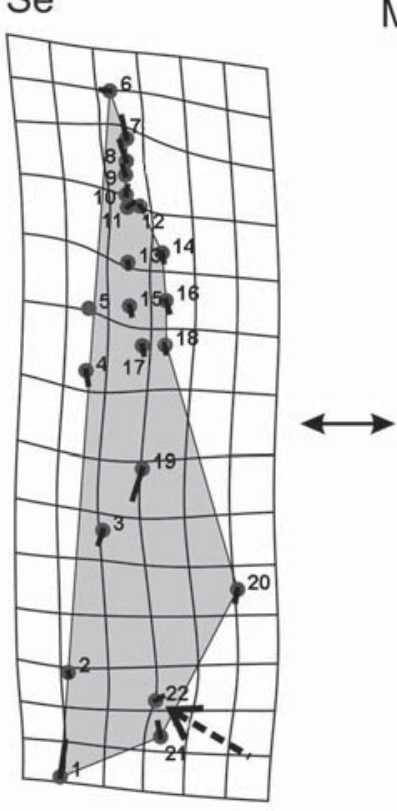

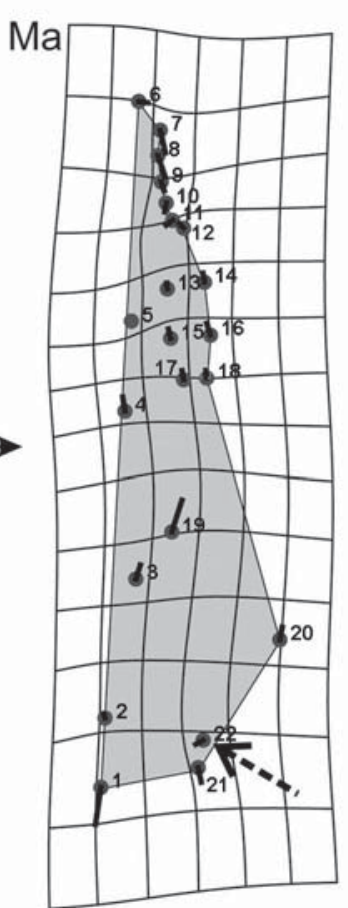

Se_V

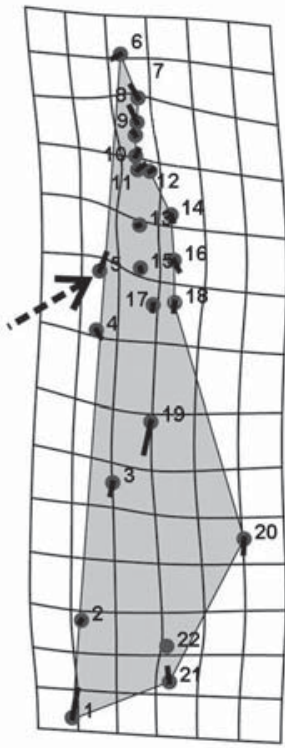

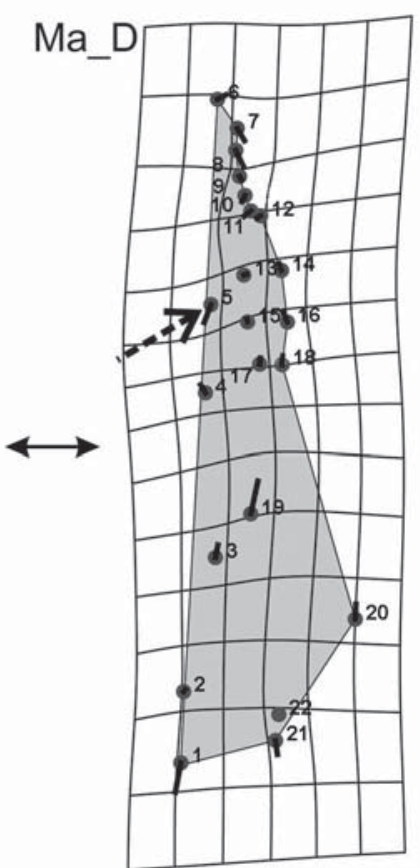

Figure 7. Transformation grids visualize shape deformation between two races (left pair - Serov vs Manturovo), and two samples (right pair - Se_V "Yaksha" vs Ma_D "Dan") by result of discriminant analysis. The dotted arrows show shape variation in 5th and 22th landmarks which are absent in another pair. 
Table 3. Divergence in quantitative characters at three hierarchical levels.

\begin{tabular}{|l|l|c|c|c|c|}
\hline \multicolumn{2}{|c|}{} & Skull size & Skull shape & Mandible shape & Molar shape \\
\hline \multirow{2}{*}{$\begin{array}{l}\text { Between } \\
\text { populations of } \\
\text { the same races }\end{array}$} & entire samples & $0.27 \pm 0.17$ & $0.060 \pm 0.004$ & $0.089 \pm 0.016$ & $0.117 \pm 0.113$ \\
\cline { 2 - 6 } & without Serov & $0.08 \pm 0.01$ & $0.064 \pm 0.005$ & $0.096 \pm 0.005$ & $0.119 \pm 0.14$ \\
\cline { 2 - 6 } $\begin{array}{l}\text { Between } \\
\text { populations of } \\
\text { different races }\end{array}$ & entire samples & $0.47 \pm 0.25$ & $0.075 \pm 0.03$ & $0.062 \pm 0.024$ & $0.14 \pm 0.009$ \\
\cline { 2 - 6 } & without Serov & $0.07 \pm 0.02$ & $0.061 \pm 0.015$ & $0.066 \pm 0.026$ & $0.20 \pm 0.034$ \\
\hline \multirow{3}{*}{\begin{tabular}{l} 
Between races \\
\cline { 2 - 6 }
\end{tabular}} & entire samples & $0.18 \pm 0.09$ & $0.022 \pm 0.001$ & $0.025 \pm 0.001$ & $0.044 \pm 0.005$ \\
\cline { 2 - 6 } $\begin{array}{l}\text { Between } \\
\text { karyotypic } \\
\text { groups }\end{array}$ & without Serov & $0.03 \pm 0.01$ & $0.019 \pm 0.003$ & $0.019 \pm 0.012$ & $0.006 \pm 0.002$ \\
\cline { 2 - 6 } & 24 races* & $0.04 \pm 0.02$ & $0.04 \pm 0.001$ & $0.01 \pm 0.001$ & $0.01 \pm 0.001$ \\
\cline { 2 - 6 } & entire samples & 0.11 & 0.15 & 0.084 & 0.134 \\
\cline { 2 - 6 } & without Serov & 0.02 & 0.004 & 0.011 & 0.111 \\
\hline
\end{tabular}

* - magnitude of $F_{s t}$ from Polly (2007).

Isolation by distance. A disparity between remote samples could result from the limitation of gene flow by distances, and the differences are expected in this case to increase with the increasing of geographic distance between samples. In fact, we did not find a significant correlation of the pairwise $Q_{s t}$ value along geographic distances among the studied samples in any of the census characteristics (Fig. 8).The correlation coefficient between geographic distance with skull size was $r=$ $0.07, r=0.06, r=0.21$, and $r=-0.18$ with the skull, mandible and molar shape, respectively. Low correlations could result from the high deviation of the "mountain" samples of the Serov race from lowland samples. In order to avoid the influence of size, we excluded the "mountain" samples of the Serov race from the analyses. However, in this case, $Q_{s t}$ magnitude does not correlate with geographic distance between samples. After Se H and Se F were omitted, the correlation in skull size became negative but remained very weak, $r=$ -0.07 , and not significant. After removing the highaltitude samples, the correlations with shape were $r=$ $-0.03, r=0.14$, and $r=-0.1$ in skulls, mandibles, and molars, respectively. To understand whether the lack of correlation is related to genetic differences between races, we plotted $Q_{\text {st }}$ between samples of the same race against geographic distance. Again, the lack of significant correlation remained; in skull size, $r=-0.43$ both in the analyses including and excluding "mountain" samples; in skull shape, it made $r=0.25$, and $r=0.02$; in mandible, shape comprised $r=0.02$, and $r=-0.02$; in molar shape, $r=0.51$, and $r=0.35$, respectively (Fig. 8).

\section{Discussion}

Although a number of researchers have found morphological differences between the chromosomal races of Sorex araneus (Chętnicki et al., 1996; Polyakov et al., 2002; Okulova et al., 2007), in most studies, morphometric variability was unassociated with racial boundaries (Sulkava et al., 1985; Searle \& Thorpe, 1987; Wójcik et al, 2000; Banaszek et al., 2003; Mishta, 2007). Morphological difference was found in cases when the races differed in size. In cases when morphological differences were not associated with races, authors indicated that variability was associated with geographic position. So, an issue whether differences in sizes are related to some environmental gradients should be discussed first. There are two known principal regularities in morphological variability of the common shrew.

(A) It was shown that highland races of the common shrew are bigger in size (Homolka, 1980; Polly, 2007). Results of our analysis of centroid size in the races and among geographic samples of the $S$. araneus substantially corresponded with previous studies (Homolka, 1980; Polly, 2007; Shchipanov et al., 2011; Bobretsov et al., 2012). Studied samples of the Serov race (Se F and $\mathrm{Se} \mathrm{H}$ ) from altitudes of $300-550 \mathrm{~m}$ were significantly larger in comparison to the other samples in centroid size of the skull and mandible. Geometric morphometrics gives a facility to evaluate the expression of allometric effects (O'Higgins \& Collard, 2002; Cardini \& Tongiorgi, 2003; Franklin et al., 2010). In our study, a negative significant correlation between RW1 and CS related to altitude was found in Serov race. Apparently, increasing the overall size of the animals leads to changes in the proportions of the skull. Based on our samples, we could note that increasing size was directly related to altitude. Lowland and "mountain" samples of the race were significantly different in size. Indeed, the Serov race as a whole entity was significantly larger in size as compared to the lowland 

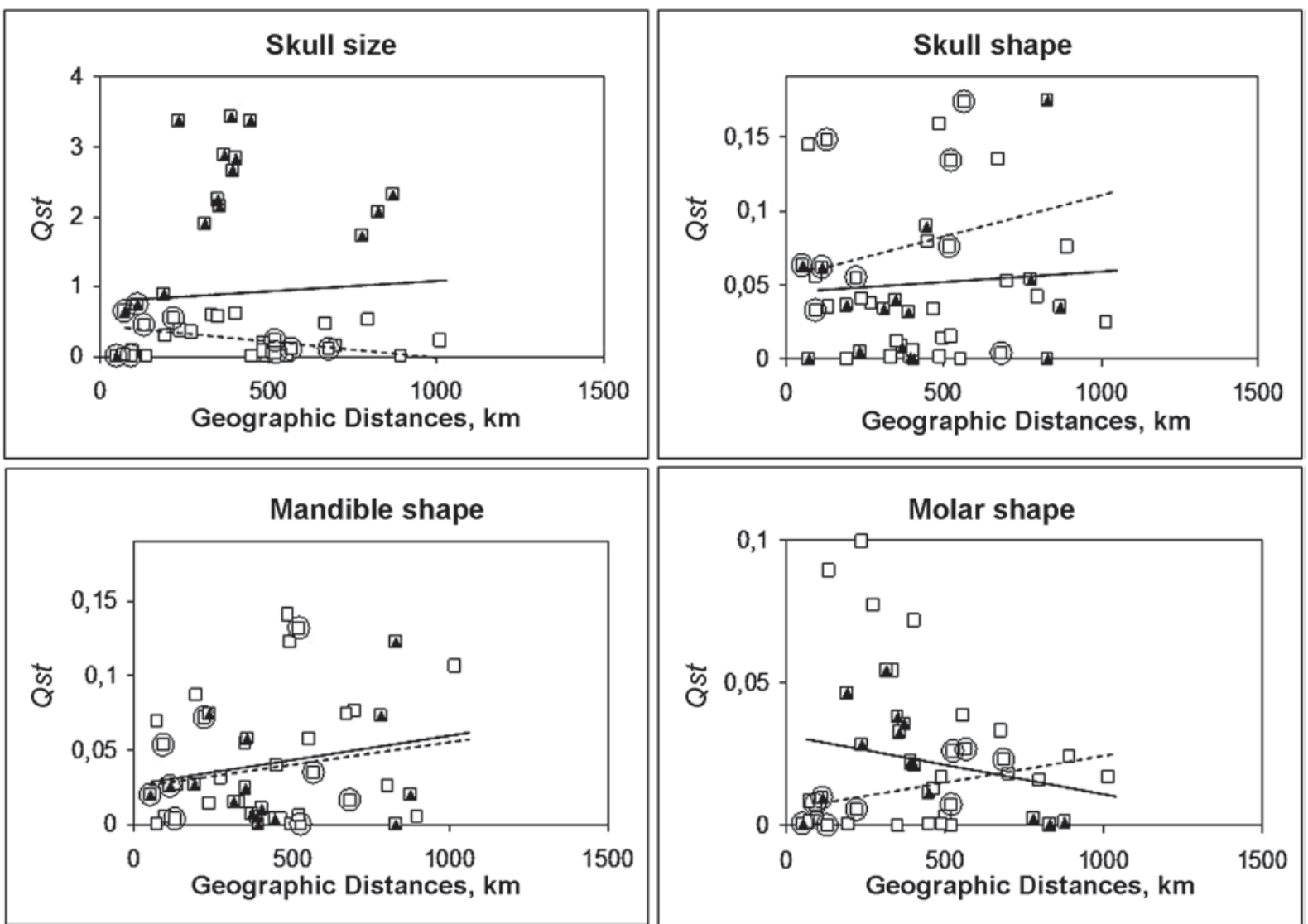

Figure 8. Isolation by distance in skull centroid size, skull shape, mandible shape and molar shape. Solid line represent linear regression in the entire set of samples, and dotted line represent the regression merely for distances within the races.

races; however, it should be emphasized that this difference as estimated for the entire race (three samples) resulted from significantly larger sizes of the two "mountain" samples. When highland samples were excluded from analyses, significant discrimination of the race between samples of different races was not found. Thus, morphological variability in the "mountain" Serov race was attributed to altitude rather than to its genetic specifics.

(B) A tendency to size reduction was found in soricines in northern populations (Ochocińska \& Taylor, 2003; Polly, 2007; Shchipanov et al., 2011). In particular, Polly (2007) found that the northern Savukoski, Kuhmo, Hällefors, and Öland races from Sweden and Finland were significantly smaller. Ochociñska and Taylor (2003) considered the diminution in size for the northern samples of $S$. araneus an exception to Bergman's rule. Also, the diminishing size was interpreted as a tendency to shift towards $r$-strategy (Shchipanov et al., 2011). We can not underpin the idea by our current results. There were southerly samples of the Manturovo $(\mathrm{Ma} \mathrm{R})$ and the Sok (So St) races with smaller centroid size as compared to the sole sample (Pt_U) of the Pechora. However, although the Pechora sample was not smaller than those two samples of the more southerly races, we note that the mean value of centroid size in that sample was smaller than the mean value in the entire sample of both the Manturovo and Sok races. It should be noted here that a trend of diminishing of common shrews in sizes at higher latitudes was found based on the analyses of many samples from various races ranging in location from the 40th to 60th parallels (Polly, 2007). All our samples were collected within a smaller range of latitudes. The border samples Pt_U and So_K came from $65^{\circ}$ and $57^{\circ}$, respectively, and all the rest were collected between $61^{\circ}$ and $62.5^{\circ}$ north latitude. We considered that it is of interest to provide more volumes of study of morphological variability in populations within and between the races with respect to latitudinal localization of samples.

Comparison of our results with studies of different authors showed that the skull, mandible, and $\mathrm{m} 1$ have different discriminating abilities. Polly (2007) found the greatest differentiation in the mandible and $\mathrm{m} 1$, the latter of which is especially important in the analysis of paleontological material (Polly, 2001, 2003). In our study, both the mandible and molar shape $Q_{s t}$ revealed good structuring at the level of karyotypic group, which was no less than at the population-level structuring. Those characteristics were less susceptible to size of the specimens. At least removal of larger sizes in the Serov race samples does not significantly influence $Q_{s t}$ 
magnitude in interpopulation and interracial comparisons. Skull shape was sensitive to the size of a specimen. When the Serov samples were omitted from the analyses, $Q_{s t}$ dropped drastically. Differences between karyotypic groups were greater as compared with population differences in all of the studies where the Serov race was included. Without the race, the differences between karyotypic groups were significantly smaller. High interpopulation diversity overwhelms structuring at the racial level in the species. Results of MANOVA ( $F$-test) for skull, mandible, and $\mathrm{m} 1$ showed significant differences when comparing both the races and local samples of the same race. Hotelling's test showed significant isolation of the races (except for Manturovo and Pechora races by $\mathrm{m} 1$ ). However, Hotelling's test identified an inconsistency between the results of paired comparisons of interracial and interpopulation shape of the skull, mandible, and m1. In particular, samples varied significantly within a race (e.g., So_K vs So_PZ by skull; So_K vs So_SL by mandible; Ma_R vs Ma_D by $\mathrm{m} 1$ ) or a lack of differences between samples of different races was found (Se_V vs Ma_D by mandible; Se_F vs Pt_U by $\mathrm{m} 1$ ). Therefore, discrimination between the races rather may reflect differences between certain samples when the number of analyzed patterns is small. Overall, our analysis of interracial and interpopulation variability showed that consistency between morphological and karyological variability can be detected in karyotypic groups. Significant discrimination between races was not possible. Discrimination of the Serov race was provided by "mountain" samples, whereas without those samples, differences were not significant. As a result, we did not find clear morphological markers attributed to race. Summarizing the results of our study with respect to discrimination of karyotypically different entities in the common shrew, we should note that (a) population variability within races is very large and exceeds interracial variability in a number of cases, and (b) correct identification of races based on morphological features may be achieved when it is shown that additional samples no longer affect the general characteristics of the variation of the race parameters.

One may assume that variability between local populations results from susceptibility of the common shrew to environment quality. Such a study was performed in Białowieża (Wójcik et al., 2003b). The authors found that there were no significant relations between morphometric variation and environmental heterogeneity in a population of the common shrew. The differences observed could be rather considered as within-population differentiation related to environmental heterogeneity. Our material does not permit a similar estimation; however, we did not find a correlation of morphometric characters with geographic variables except altitude. Note that climatic factors at an altitude of $500 \mathrm{~m}$ in Ural are similar to those at the locality where the Pechora race was collected. Both areas fall into the North taiga natural zone, with mossy spruce forests as a principal vegetation and with a predominance of Siberian spruce (Picea obovata) among trees. However, alternative tendencies in sizes of the Pechora and Serov race could be indicated. All the rest of the samples were collected within the area of the European Mid Taiga natural zone and are rather similar in terms of vegetation. It should be noted that the common shrew inhabited all types of the habitats in the region (Kuprianova, 1976, 1994; Bobretsov, 2004), and anthropogenic influence is minimal over almost all the studied area (Degteva, 2006). Thus, although we did not make special analyses, we consider that significant interpopulation morphometric distances were unlikely related to the environmental specifics. On the other hand, we found that morphological structuring is complicated by the variation of inter-pattern differences from trait to trait. Discriminant analysis revealed indeterminate variability in interracial and interpopulation comparisons. There were different discriminating features in each pair of samples, regardless of race. Different landmarks were useful for discriminating between samples in each pair. Each peculiar feature may give a high accuracy of discrimination between a pair of samples of different races but will not be actual at another pair of samples of those races or at a level of entire races. Thus, any discriminating features that had been found for a pair of samples can not be considered significant for discrimination between races a priori. The results of the race discrimination were dependent on a particular set of samples involved in the analysis. The same trend in discrimination between different samples was found in traditional morphological studies (Shchipanov et al., 2011; Bobretsov et al., 2012).

A high level of diversity in the samples irrespective of race could be explained by genetic drift in recently isolated populations that had equivalent sets of genetic markers initially. The predominance of indeterminate variability in local samples with relatively low interracial differentiation is in good agreement with the "sudden expansion" model which was based on molecular studies (Ratkievicz et al., 2002). The idea of sudden expansion is based on the allozyme and molecular studies. Only slight differences in haplotype frequencies among populations from different karyotypic groups and races were found. Intrapopulation variability chiefly contributes to general diversity; it made it about $70 \%$ (Andersson, 2004). Haplotypes did not show phylogeographic structuring but revealed star-like phylogeny (Ratkiewicz et al., 2002). The idea of sudden expansion was confirmed in studies of mt-DNA and microsatellites of Scandinavian races from two karyotypic groups (Andersson, 2004). Also, in some of the localities of the present study, inter- and intra-racial molecular variability was estimated using cytochrome $b$, and significant difference among all the samples was found (Raspopova \& Shchipanov, 2011). Our morphometric study is congruent to the results of molecular studies and allows us to assume that stochastic changes of alleles in frequencies are one of important drivers of divergence of 
local populations. Obviously, migration should hamper interpopulation divergence; hence, one would not find significant differentiation between local samples if interpopulation migration is unlimited. Also, when interpopulation migration is not limited, one should find correlation of the level of divergence with distance in the case of remote samples. In fact, we observed significant structuring at a level of local populations and a lack of correlation of the level of divergence with geographic distance between studied samples. The idea of discontinuity between local populations is in good agreement with microsatellite studies. Significant population structuring of the common shrew was noted in many studies (Wyttenbach et al., 1999; Lugon-Mouline et al., 1999, 2000; Andersson, 2004; Horn et al., 2012). Magnitude of $F_{s t}$ was not different, notably, in comparisons of samples of the same race and between different races. What's more the magnitude was significantly lower at the racial level as compared with the population level. We have observed the same effects in our morphometric studies. One could hypothesize that the effects of genetic drift in partly isolated populations could contribute to morphological diversity at the population level. Based on mark-recapture and homing studies, and such natural marker of movements as micromycetes spores composition on fur of individuals, Shchipanov (2007) indicated that there are some evidences of limited migration between neighboring populations of the common shrew of the same race in the absence of any environmental obstacles. He supposed that limitation of gene flow could be related to the specifics of dispersal of common shrews in a core and peripheral area of a local population. However, this issue remained unclear and required more studies. Nevertheless, morphological studies likely provide evidence of subdivision of the species at the population level. At least we could note here that levels of morphological differentiation are compatible with results of molecular and enzyme studies.

Lack of expected range of differences between the races could be explained by the reabsorption of local changes due to gene flow in the metapopulaion, as was supposed by Polly (2007). In this case, a high population-level structuring in comparison to relatively low interracial differences may not be an evidence of unlimited gene flow between different races. Thus, a conclusion about unlimited gene flow between different races of the common shrew based on the microsatellite study (Horn et al., 2012) could be a sort of paradox. Supposedly, we observe an effect of limitation of migration between local populations both at the intra-racial and interracial levels. At least, we could note that in our study, the level of $Q_{s t}$ was not different between populations both within and between the races. Indeed, Polly (2007) has found significant morphometric discrimination between the races, though it was small. Regarding relatively small morphological distances at the racial level, Polly et al. (2013) anticipated that phenotypic differentiation has been lost through gene flow since post-glacial secondary contact, but now, there is no free gene flow across the hybrid zones. Indeed, appearance of the most contemporary chromosomal races is assumed to be attributed to the last glaciation (Hausser, 1994; Searle \& Wójcik, 1998; Fredga \& Narain, 2000; Polyakov et al., 2001; Ratkievicz et al., 2002; Wójcik et al., 2002; Brünner et al., 2002; Fredga, 2007; Orlov et al., 2007) However, the ancestors for the karyotypic groups are likely to have arisen earlier. Polly (2001) argued using fossil evidence that phylogenetic division among at least some $S$. araneus karyotypic races extended for at least 100000 years ago. In this case, the relatively high level of divergence between karyotypic groups could be explained by long-term isolation of the ancestral populations in different parts of the range of the species, hence fitting to a rather different environment. Attribution of different ancestor races to geographically different refugees is argued in a number of studies (Searle \& Wójcik, 1998; Brünner et al., 2002; Fredga, 2007; Orlov et al., 2007). So, our results are consistent with the hypotheses of the formation of modern ranges of karyotypic groups under the influence of late Pleistocene glaciations (Searle \& Wójcik, 1998; Polly, 2001, 2003).

Because of its high chromosomal polymorphism, the common shrew represents a good model for studies that are not common in the other species (Shchipanov et al., 2009) and, in particular, for large-scale study of phenotypic variability with respect to genetic structure of the population. This permits us to discuss an issue that is not directly related to the common shrew, however, which could contribute to applied studies. Beklemishev (1960) suggested distinguishing "independent populations" - sets of interacting local populations, subpopulations in Beklemishev's terminology, which are operating independently from other similar "independent populations". In fact, Beklemishev's idea is quite close to the metapopulation concept (Levins, 1969; Hanski, 1999). Population abundance in each subpopulation depends on population abundance of surrounding local populations, and each subpopulation is maintained through balance of immigration and emigration. Also, Beklemishev (1960) distinguished a set of subpopulations where population abundance results merely from balance of reproduction and mortality rates and that is independent in functioning from other similar sets. The idea originated from his applied studies. It was found that when a treatment touched a whole area of an "independent population", a long-term effect was achieved, whereas when the parts of different "independent populations" were treated, the recovery went swiftly (Beklemishev, 1960). Migration rate was expected to be relatively low between "independent" populations, whereas it should be relatively high within an "independent population". We think that such limitation of migration of individuals, and hence hampering of gene flow, may result in selection of unique genotypes or unique gene pools. Thus, distinguishing "independent populations" could be valuable from both perspectives of conservation of biotic diversity and population management. However, Beklemishev's concept is not wide- 
spread chiefly due to a lack of easy indicators of "independence". Lack of synchronicity of population dynamics was firstly suggested as a criterion. Naumov (1963) noted lack of synchronicity in population dynamics of red squirrels in Siberia and supposed it was an indicator for "independent" populations. Also, independent population fluctuations were noted in neighboring populations of lemmings and voles at Chukchi Peninsula (Shchipanov, 2002). The lack of synchronicity in dynamics was found between populations of the common shrew that were removed at about $4 \mathrm{~km}$ of distance (Shchipanov et al., 2005). However, it should be emphasized that the phenomenon was not found in three other species of Sorex, which were monitored together with the common shrew, and the lack of synchronicity in the case of $S$. araneus was attributed to population specifics of the latter species (Shchipanov et al., 2005). Analyzing population reaction to the "pest control" and following natural disasters, Shchipanov $(2002,2003)$ suggested that lack of synchronicity could be found merely in species with a specific mode of population functioning, i.e. in those who may produce population fluctuations due to oscillation of frequencies of various genotypes, similar to the Chitty (1967) hypothesis. In species with other modes of functioning of population, the population abundance depends chiefly on environmental fluctuations, and so, the limitation of population exchange can not be found as "independence" in population dynamics. Thus, the idea of using synchronicity in fluctuations of population abundance can not be used as a universal criterion. Another obstacle for application of the criterion is that the lack of synchronic dynamics can not be found without longterm surveillance of populations. Therefore, population dynamics is not an appropriate tool for operational revealing of "independent populations".

In population genetics, limited migration is measured as Wright's (1951) $F_{s t}$, which can be used as a measure of isolation and also to calculate effective migration rates and times since population divergence. The measure implies estimation of average probability of identity in states of alleles in each population. Such estimations are based on revealing specific genetic traits, and special genetic studies are required. The past two decades give an opportunity for relatively easy estimation of gene flow based on microsatellite allele frequencies. Indeed, using microsatellites as markers in hierarchical analyses of genetic differentiation is appropriate because of their high mutation rate. Taking into account specific mutation process in microsatellite loci, Slatkin (1995) suggests analogous statistics, $R_{s t}$, in order to measure population subdivision. In both cases, the principal idea was to find significant differences in allele frequencies that could be produced by the limited exchange between contacting populations, which is completely compatible with the idea of finding "independent populations". Although molecular analysis gives undeniable facts, it is a rather sophisticated procedure that requires specific volumetric studies. Meanwhile, skull collections are generally available. In many cases, skull collection is a by-product of monitoring populations of small mammals under removal trapping. We suppose that morphological characteristics could also be used for similar estimations. One could note that the level of divergence at different hierarchical levels was quite near to estimations obtained from different set of races (Polly, 2007). Relatively high values of $Q_{s t}$ of the skull size resulted from a greater proportion of the larger individuals of the Serov race in our set of samples. Without the Serov race, we obtained almost the same magnitudes as Polly's (2007) $F_{s t}$. Similarities in magnitude of $Q_{s t}$ and $F_{s t}$ in both studies are likely evidence that the structuring in a great number of cases is likely driven by the same factors. Whether the differences observed chiefly result from genetic drift in partly isolated local populations, one could anticipate using morphometric estimations as a criterion to distinguish "independent populations". However, to confirm the idea, the direct studies of parallelism in estimations of genetic and morphometric population structuring are required.

\section{Conclusion}

We found increasing size of individuals with altitude and significant population-level structuring in the morphology of the common shrew, including structuring at levels of diversity marked by karyotype differences, confirming the results of some previous studies. Population-level structuring suggests limitation of migration, hence gene flow, between small local populations of the species. Stochasticity of the signs discriminating different pairs of populations apparently results from genetic drift. Understanding of the specific processes resulting in the limitation of gene flow at the population level could contribute to our understanding of initial stages of divergence. We consider, it is of interest to estimate minimal distance between significantly discriminating samples in future studies.

ACKNOWLEDGEMENTS. We are grateful to our colleagues: A.O. Averianov, F.N. Golenishchev, A.A. Kalinin, S.V. Pavlova, E.A. Pertova, G.I. Baranova, A.Yu. Puzachenko, N.E. Dokuchaev. Separately, thank P.D. Polly for his help in preparing the manuscript and discussion of results. This study was partly supported by the Ministry of Education and Science of Russian Federation, RFBR 10-06-00060a, RFBR 11-04-90722mob_st, RFBR 12-04-00937-a, RFBR 13-04-00525-a, Program "Biodiversity" of Presidium of the Russian Academy of Sciences, Project \# VIII.76.3.5. of Fundamental Researches of the Siberian Division of the Russian Academy of Sciences.

\section{References}

Andersson A.-C. 2004. Postglacial population history of the common shrew (Sorex araneus) in Fennoscandia: Molecular studies of recolonisation, sex-biased gene flow 
and the formation of chromosome races // Comprehensive Summaries of Uppsala Dissertations of the Faculty of Science and Technology. Vol.986. P.1-56.

Banaszek A., Smakulska J., Fedyk S., Jadwiszczak K.A. \& Chętnicki W. 2003. Morphometric differentiation of shrews Sorex araneus L., 1758 from the hybrid zone between Guzovy Młyn and Lęucki Młyn chromosomal races in Poland // Mammalia. Vol.67. P.217-224.

Barton N.H. \& Hewitt G.M. 1985. Analysis of hybrid zones // Annual Review of Ecology, Evolution, and Systematics. Vol.16. P.113-148.

Beklemishev V.N. 1960. [Spatial and functional structure of population] // [Bulletin of the Moscow Society of Naturalists. Biological Series]. Vol.65. P.41-45 [in Russian].

Bookstein F.L. 1991. Morphometric Tools for Landmark Data: Geometry and Biology. Cambridge: Cambridge University Press. 435 p.

Bobretsov A.V. 2004. [The common shrew] // Kuprianov A.G. (ed.). Mlekopitaushchie Pechoro-Ilychskogo Zapovednika. Syktyvkar: Komi knizhnoe izdatelstvo. P.4664 [in Russian].

Bobretsov A.V., Kuprianova I.F., Kalinin A.A., Petrov A.N., Pavlova S.V. \& Shchipanov N.A. 2012. [Morphological differentiation of the common shrew (Sorex araneus) in the north-eastern European Russia] // Zoologicheskii Zhurnal. Vol.91. P.605-618 [in Russian, with English summary].

Bolshakov V.N., Vasiliev A.G. \& Sharova L.P. 1996. [Fauna and Population Ecology of Shrews in Ural (Mammalia, Soricidae)]. Yekaterinburg: Izdatelstvo Ekaterinburg. 268 p. [in Russian]

Brünner H., Lugon-Moulin N., Balloux F., Fumagalli L. \& Hausser J. 2002. A taxonomical re-evaluation of the Valais chromosome race of the common shrew Sorex araneus (Insectivora: Soricidae) // Acta Theriologica. Vol.47. P.245-275.

Bulatova N., Jones R.M., White T.A., Shchipanov N.A., Pavlova S.V. \& Searle J.B. 2011. Natural hybridization between extremely divergent chromosomal races of the common shrew (Sorex araneus, Soricidae, Soricomorpha): hybrid zone in European Russia // Journal of Evolutionary Biology. Vol.24. P.573-586.

Bystrakova N.V., Shchipanov N.A., Bulatova N.Sh., Sheftel B.I., Nadjafova R.S., Pavlova S.V., Demidova T.B., Bobretsov A.V., Aleksandrov D.Yu., Kalinin A.A., Kouptsov A.V., Volkova A.T., Oleinichenko V.Yu. \& Searle J.B. 2007. New data on the geographic distribution of chromosome races of Sorex araneus (Soricidae, Eulipotyphla) in European Russia // Russian Journal of Theriology. Vol.6. No.1. P.105-109.

Cardini A. \& Elton S. 2008. Does the skull carry a philogenetic signal? Evolution and modularity in the guenons // Biological Journal of the Linnean Society. Vol.93. P.813834.

Cardini A. \& Tongiorgi P. 2003. Yellow-bellied marmots "in the shape space": sexual dimorphism, growth and allometry of the mandible // Zoomorphology. Vol.122. P.11-23.

Caumul R. \& Polly P.D. 2005. Phylogenetic and environmental components of morphological variation: skull, mandible, and molar shape in marmots (Marmota, Rodentia) // Evolution. Vol.59. P.2460-2472.
Chitty D. 1967. The natural selection of self-regulatory behaviour in animal populations // Proceedings of the Ecological Society of Australia. Vol.2. P.51-78.

Chętnicki W., Fedyk S., Banaszek A., Szalaj K.A. \& Ratkiewicz M. 1996. Morphometrical characteristics of the common shrew (Sorex araneus L.) from interracial hybrid zones // Hereditas. Vol.125. P.201-207.

Churchfield S. 1990. The Natural History of Shrews. London: Christopher Helm Press. 178 p.

Dehnel A. 1949. Studies on the genus Sorex L. // Annales Universitatis Mariae Curie-Sklodowska. Vol.4. P.17102.

Degteva S. 2006. Plant communities // Taskaev A.I. (ed.). Virgin Forests of Komi. Moscow: Publishing Center of Design, Information, Cartography. P.88-115.

Dolgov V.A. 1985. [Red-toothed Shrews of the Old World]. Moskva: Izdatelstvo MGU. 221 p. [in Russian]

Franklin D., Cardini A. \& Oxnard Ch. 2010. A geometric morphometric approach to the quantification of population variation in Sub-Saharan African crania // American Journal of Human Biology. Vol.22. P.23-35.

Fredga K. 2007. Reconstruction of the postglacial colonization of Sorex araneus into northern Scandinavia based on karyotype studies, and the subdivision of the Abisko race into three // Russian Journal of Theriology. Vol.6. No.1. P.85-96.

Fredga K. \& Narain Y. 2000. The complex hybrid zone between the Abisko and Sidensjö chromosome races of Sorex araneus in Sweden // Biological Journal of the Linnean Society. Vol.70. P.285-307.

Frykman I. \& Bengtsson B.O. 1984. Genetic differentiation in Sorex. III. Electrophoretic analyses of a hybrid zone between two karyotypic races in Sorex araneus // Heriditas. Vol.100. P.259-270.

Frykman I., Simonsen V. \& Bengtsson B.O. 1983. Genetic differentiation in Sorex. I. Electrophoretic analyses of the karyotypic races of Sorex araneus in Sweden // Heriditas. Vol.99. P.279-292.

Gureev A.A. 1979. [Insectivores. Hedgehogs, Moles and Shrews (Erinaceidae, Talpidae, Soricidae). Fauna USSR, Mammals]. Vol.4. No.2. Leningrad: Nauka. 503 p. [in Russian]

Hammer Ø., Harper D.A.T. \& Ryan P.D. 2001. Paleontological statistics software package for education and data analysis // Palaeontologia Electronica. Vol.4. P.1-9.

Hanski I. 1999. Metapopulation Ecology. Oxford: Oxford University Press. 328 p.

Hausser J. 1994. The Sorex of the araneus-arcticus group (Mammalia, Soricidae): do they actually speciate // Merrit J.F., Kirkland G.L. \& Rose R.K. (eds.). Advances in the Biology of Shrews. Pittsburgh: Special Publication of Carnegie Museum of Natural History. Vol.18. P.295-306.

Hausser J., Fedyk S., Fredga K., Searle J.B., Volobuev V., Wójcik J. \& Zima J. 1994. Definition and nomenclature of chromosome races of Sorex araneus // Folia Zoologica. Vol.43. P.1-9.

Hausser J., Hutterer R. \& Vogel P. 1990. Sorex araneus Linnaeus, 1758 - Waldspitzmaus // Niethammer J. \& Krapp F. (eds.). Handbuch der Säugetiere Europas. Insektenfresser, Herrentiere. Wiesbaden: AULA-Verlag. Bd.3. S.237-278 
Homolka M. 1980. Biometrisher Vergleich zweier Populationen Sorex araneus // Acta Scientiarum Naturalium Academiae Scientiarum Bohemicae Brno. Bd.14. S.1-34.

Horn A., Basset P., Yannic G., Banaszek A., Borodin P.M., Bulatova N.Sh., Jadwiszczak K., Jones R.M., Polyakov A.V., Ratkiewicz M., Searle J.B., Shchipanov N.A., Zima J. \& Hausser J. 2012. Chromosomal rearrangements do not seem to affect the gene flow in hybrid zones between karyotypic races of the common shrew (Sorex araneus) // Evolution. Vol.66. P.882-889.

Hutterer R. 2005. Order Soricomorpha // Wilson D.E. \& Reeder D.M. (eds.). Mammal Species of the World. A Taxonomic and Geographic Reference. Third edition. Baltimore: Johns Hopkins University Press. Vol.2. P.220311.

Jiggins C.D. \& Mallet J. 2000. Bimodal hybrid zones and speciation // Trends in Ecology \& Evolution. Vol.15. P. 250-255.

Key K.H.L. 1968. The concept of stasipatric speciation // Systematic Zoology. Vol.17. P.14-22.

Klingenberg C.P. 2011. MorphoJ: an integrated software package for geometric morphometrics // Molecular Ecology Resources. Vol.11. P.353-357.

Kuprianova I.F. 1976. [Abundance and biotopic relations in red-toothed shrews in Arkhangelsk area] // Miheev A.V. (ed.). Fauna i Ekologia Zhivotnykh. Moskva: MGPI. Part 2. P.170-185 [in Russian].

Kuprianova I.F. 1994. [The common shrew] // Bolshakov V.N. (ed.). Fauna Evropeiskogo Severo-Vostoka Rossii. Mlekopitayushchie. Sankt-Peterburg: Nauka. Vol.2. Part 1. P.11-25 [in Russian].

Levins R. 1969. Some demographic and genetic consequences of environmental heterogeneity for biological control // Bulletin of the Entomological Society of America. Vol.15. P.237-240.

Lugon-Mouline N., Balloux F. \& Hausser J. 2000. Genetic differentiation of common shrew Sorex araneus populations among different alpine valleys revealed by microsatellites // Acta Theriologica. Vol.45. P.103-117.

Lugon-Mouline N., Brünner H., Wyttenbach A., Hausser J. \& Goudet J. 1999. Hierarchical analyses of genetic differentiation in a hybrid zone of Sorex araneus (Insectivora: Soricidae) // Molecular Ecology. Vol.8. P.419431.

Meyer A. \& Searle J.B. 1994. Morphological studies on British common shrews // Folia Zoologica. Vol.43. P.115.

Mishta A.V. 2007. Morphometric variation of the common shrew Sorex araneus in Ukraine, in relation to geoclimatic factors and karyotype // Russian Journal of Theriology. Vol.6. No.1. P.51-62.

Moska M. \& Paœko Ł. 2006. Morphometric variation between karyological categories of the common shrew (Sorex araneus) in the Legucki Młyn/Popielno hybrid zone // Electronic Journal of Polish Agricultural Universities. Veterinary Medicine. Vol.9. No.1.

Naumov N.P. 1963. [Animal Ecology]. Moskva: Vysshaya Shkola. 618 p. [in Russian]

Ochociñska D. \& Taylor J.R.E. 2003. Bergmann's rule in shrews: geographic variation of body size in Palearctic Sorex species // Biological Journal of Linnaean Society. Vol.78. P.356-381.
O'Higgins P. \& Collard M. 2002. Sexual dimorphism and facial growth in papionin monkeys // Journal of Zoology. Vol.257. P.255-272.

Okulova N.M., Balakirev A.E. \& Orlov V.N. 2007. Craniometrical characteristics of some Sorex araneus chromosomal races // Russian Journal of Theriology. Vol.6. No.1. P.63-71.

Orlov V.N., Bulatova N.Sh., Kozlovsky A.I. \& Balakirev A.E. 2004. [Hierarchy of intraspecific taxa of the common shrew, Sorex araneus (Insectivora), and taxonomic structure of species in mammals] // Zoologicheskii Zhurnal. Vol.83. P.199-212 [in Russian, with English summary].

Orlov V.N., Kozlovsky A.I., Okulova N.M. \& Balakirev A.E. 2007. Postglacial recolonisation of the European Russia by the common shrew Sorex araneus // Russian Journal of Theriology. Vol.6. No1. P.97-104.

Pavlova S.V., Bystrakova N.V., Bulatova N., Nadjafova R.S. \& Polyakov A.V. 2006. [The cadastre of chromosome races of the common shrew Sorex araneus L. (in Russia)] // Biogeographia. Vol.13. P.42-59 [in Russian with English summary].

Polly P.D. 2001. On morphological clocks and paleophylogeography: towards a timescale for Sorex hybrid zones / / Genetica. Vol.112-113. P.339-357.

Polly P.D. 2003. Paleophylogeography of Sorex araneus: molar shape as a morphological marker for fossil shrews // Mammalia. Vol.67. P.233-242.

Polly P.D. 2007. Phylogeographic differentiation in Sorex araneus: morphology in relation to geography and karyotype // Russian Journal of Theriology. Vol.6. No.1. P.73-84.

Polly P.D., Polyakov A.V., Ilyashenko V.B., Onischenko S.S., White T.A., Shchipanov N.A., Bulatova N.Sh., Pavlova S.V., Borodin P.M. \& Searle J.B. 2013. Phenotypic variation across chromosomal hybrid zones of the common shrew (Sorex araneus) indicates reduced gene flow // PLoS ONE. 8 (7): e67455. P.1-12.

Polyakov A.V., Panov V.V., Ladygina T.Yu., Bochkarev M.N., Rodionova M.I. \& Borodin P.M. 2001. Chromosome evolution of the common shrew Sorex araneus L. in postglacial time in the South Ural and Siberia // Russian Journal of Genetic. Vol.37. P.448-455.

Polyakov A.V., Onischenko S.S., Ilyashenko V.B., Searle J.B. \& Borodin P.M. 2002. Morphometric difference between the Novosibirsk and Thomsk chromosome races of Sorex araneus in a zone of parapatry // Acta Theriologica. Vol.47. P.381-387.

Polyakov A.V., White T.A., Jones R.M., Borodin P.M. \& Searle J.B. 2011. Natural hybridisation between extremely divergent chromosomal races of the common shrew (Sorex araneus, Soricidae, Soricomorpha): hybrid zone in Siberia // Journal of Evolutionary Biology. Vol.24. P.13931402.

Polyakov A.V., Zima J., Searle J.B., Borodin P.M. \& Ladygina T.Yu. 2000. Chromosome races of the common shrew Sorex araneus in the Ural Mts: a link between Siberia and Scandinavia? // Acta Theriologica. Vol.45. P.19-26.

Poroshin E.A., Polly P.D. \& Wójcik J.M. 2010. Climate and morphological change on decadal scales: multiannual 
variation in the common shrew Sorex araneus in northeast Russia // Acta Theriologica. Vol.55. P.193-202.

Pucek M. 1965. Water contents and seasonal changes of the brain-weight in shrews // Acta Theriologica. Vol.10. P.353-367.

Pucek Z. 1963. Seasonal changes in the braincase of some representatives of the genus Sorex from the Palearctic // Journal of Mammalogy. Vol.44. P.523-536.

Pucek Z. 1970. Seasonal and age change in shrews as an adaptive process // Symposia of the Zoological Society of London. Vol.26. P.189-207.

Raspopova A.A. \& Shchipanov N.A. 2011. [Variability of a cytochrome $b$ region in different chromosome races and populations of the common shrew Sorex araneus L., 1758] // Genetika. Vol.47. No.4. P.527-536 [in Russian with English summary].

Ratkiewicz M., Fedyk S., Banaszek A., Chętnicki K.A.W., Sazałaj K.A., Gelly L. \& Taberlet P. 2002. The evolutionary history of the two karyotypic groups of the common shrew Sorex araneus, in Poland// Heredity. Vol.88. P.235-242.

Ratkiewicz M., Banaszek A., Jadwiszczak K.A., Chętnicki W. \& Fedyk S. 2003. Genetic diversity, stability of population structure and barriers to gene flow in a hybrid zone between two Sorex araneus chromosome races // Mammalia. Vol.67. P.275-284.

Rohlf F.G. \& Slice D.E. 1990. Extension of the Procrustes method for the optimal superimposition of landmarks // Systematic Zoology. Vol.39. P.40-59.

Searle J.B. 1985. Isozyme variation in the common shrew (Sorex araneus) in Britain in relation to karyotype // Heredity. Vol.55. P.175-180.

Searle J.B. 1993. Chromosomal hybrid zones in eutherian mammals // Harrison R.G. (ed.). Hybrid Zones and the Evolutionary Process. Oxford: Oxford University Press. P.309-353

Searle J.B., Fedyk S., Fredga K., Hausser J. \& Volobuev V.T. 1991. Nomenclature for the chromosomes of the common shrew (Sorex araneus) // Memoires de la Societe Vaudoise des Sciences Naturelles. Vol.19. P.13-22.

Searle J.B., Hausser J., Zima J., Fredga K., Wójcik J.M., Volobuev V.T., Bulatova N.S. \& Nadjafova R. 2008. The ISACC heritage // Russian Journal of Theriology. Vol.6 (for 2007). No.2. P.123-167.

Searle J.B. \& Thorpe R.S. 1987. Morphometric variation of the common shrew (Sorex araneus) in Britain, in relation to karyotype and geography // Journal of Zoology. Vol.212. P.373-377.

Searle J.B. \& Wójcik J.M. 1998. Chromosomal evolution: the case of Sorex araneus // Wójcik J.M. \& Wolsan M. (eds.). Evolution of Shrews. Białowieża: Mammal Research Institute, Polish Academy of Sciences. P.219268.

Shchipanov N.A. 2002. [Functional organization of population as an approach to studies of population resistance. Applied aspect (small mammals as example)] // Zoologicheskii Zhurnal. Vol.81. P.1048-1077 [in Russian, with English summary]

Shchipanov N.A. 2003. ["Population" as a cell of species] // Zoologicheskii Zhurnal. Vol.82. P.450-469 [in Russian, with English summary].
Shchipanov N.A. 2007. Understanding the boundaries between chromosome races of common shrews in terms of restricted movement by individual shrews // Russian Journal of Theriology. Vol.6. No.1. P.117-122.

Shchipanov N.A., Bobretsov A.V., Kuprianova I.F. \& Pavlova S.V. 2011. Interracial and population variability of phenotypic (cranial) characters in the common shrew Sorex araneus L., 1758 // Russian Journal of Genetics. Vol.47. P.76-86.

Shchipanov N.A., Bulatova N.Sh., Pavlova S.V. \& Shchipanov A.N. 2009. [The common shrew (Sorex araneus) as a model species in ecological and evolutionary studies] // Zoologicheskii Zhurnal. Vol.88. P.975-989 [in Russian, with English summary].

Shchipanov N.A., Kalinin A.A., Demidova T.B., Oleinichenko V.Yu., Aleksandrov D.Yu. \& Kouptzov A.V. 2005. Population ecology of red-toothed shrews, Sorex araneus, $S$. caecutiens, $S$. minutus, and $S$. isodon, in Central Russia // Merrit J.F., Curchfield S., Hutterer R. \& Sheftel B. (eds.). Advances in the Biology of Shrews II. Special Publication of the International Society of Shrew Biologists. New York: International Society of Shrew Biologists. P.201-216.

Shchipanov N.A. \& Pavlova S.V. 2013. Contact zones and ranges of chromosomal races of the common shrew, Sorex araneus, in northeastern European Russia // Folia Zoologica. Vol.62. P.24-35.

Slatkin M. 1995. A measure of population subdivision based on microsatellite allele frequencies // Genetics. Vol.139. P.457-462.

Spitze K. 1993. Population structure in Daphnia obusta: quantitative genetic and allozymic variation // Genetics. Vol.135. P.367-374

Sulkava S., Vahtola M. \& Fredga K. 1985. Structure of the upper tooth-row of Sorex araneus in Scandinavia // Acta Zoologica Fennica. Vol.173. P.237-239.

Voyta L.L., Omelko V.E. \& Petrova E.A. 2013. [Analysis of the morphometrics variability and intraspecific structure of Sorex minutissimus Zimmermann, 1780 (Lipotyphla: Soricidae) in Russia] // Proceedings of Zoological Institute RAS. Vol.317. P.332-351 [in Russian, with English summary]

White T.A., Bordewich M. \& Searle J.B. 2010. A network approach to study karyotypic evolution: the chromosomal races of the common shrew (Sorex araneus) and house mouse (Mus musculus) as model systems // Systematic Biology. Vol.59. P.262-276.

Wójcik J.M. 1991. Chromosomal polymorphism in the common shrew Sorex araneus and its adaptive significance // Mémories de la Société Vaudoise des Sciences Naturales. Vol.19. P.51-62.

Wójcik J.M. \& Wójcik A.M. 1994. Protein variation in the common shrew (Sorex araneus L.) in Poland in relation to karyotype // Folia Zoologica. Vol.43. P.53-61.

Wójcik J.M., Bogdanowicz W., Pucek Z., Wójcik A.M. \& Zalewska H. 2000. Morphometric variation of the common shrew Sorex araneus in Poland in relation to karyotype // Acta Theriologica. Vol.45. P.161-172.

Wójcik J.M., Borodin P.M., Fedyk S., Fredga K., Hausser J., Mishta A., Orlov V.N., Searle J.B., Volobuev V.T. \& Zima J. 2003a. The list of the chromosome races of the 
common shrew Sorex araneus (updated 2002) // Mammalia. Vol.67. P.169-178.

Wójcik J.M., Ratkievicz M. \& Searle J.B. 2002. Evolution of the common shrew Sorex araneus: chromosomal and molecular aspects // Acta Theriologica. Vol.47. P.139167.

Wójcik J.M., Wójcik A.M. \& Sikorski M.D. 2003b. Morphometric variation of the common shrew Sorex araneus, indifferent habitats // Mammalia. Vol.68. P.225-231.

Wójcik J.M., Wójcik A.M. \& Zalewska H. 1996. Chromosomal and allozyme variation of the common shrew, Sorex araneus, in different habitats // Hereditas. Vol.125.
P.183-189.

Wright S. 1951. The genetic structure of populations // Annals of Eugenics. Vol.15. P.323-354.

Wyttenbach A., Goudet J., Cornuet J.-M. \& Hausser J. 1999. Microsatellite variation reveals low genetic subdivision in a chromosome race of Sorex araneus (Mammalia, Insectivora) // Heredity. Vol.90. P.323-327.

Yudin B.S. 1989. [Insectivorous Mammals of Siberia]. Novosibirsk: Nauka. 360 p. [in Russian]

Zelditch M.L., Swiderski D.L., Sheets H.D. \& Fink W.L. 2004. Geometric Morphometrics for Biologists: A Primer. London: Elsevier Academic Press. 437 p.

\section{APPENDIX 1}

The list of specimens used in morphometric analysis. Information is in the following order: race name, sample abbreviation, month and year of catch in parentheses, locality, karyotypic group (see text), geographical coordinates in parenthesis, specimen number (museum catalogue number or field number), size of sample in parentheses. All specimens keeping in the Museum of the Pechora-Ilych State Nature Reserve, Yaksha, Komi Republic, Russia. Collectors: I.F. Kuprianova, A.V. Bobretsov, A.A. Kalinin, and N.A. Shchipanov.

Serov Race, Se Valley (July-August, 2001-2002), Yaksha Village, Komi Republic, Russia, NEKG (N 61.82, E $\left.56.84^{\circ}\right)-307, \overline{3} 14,328,329,333,334,337,338,366-368,371,395,403,404,412-416,420,422,424,425$, $434,435,448,453,456,460-462,472,473,476,478,481,482,484,485$, 487, 488, 526, 533-535, 544-546, 557, $558,560,562,565,573,574,615,616,618,635,1101,1109,1112-1114,1121,1122,1128-1132,1136,1137$, $1142,1147,1151,1157,1162,1164,1168,1169,1171,1175,1181,1184-1187,1189,1192,1193,1217,1221$, $1240,1241,1270,1273,1274,1275,1276,1281,1282,1285,1308(n=105)$.

Serov Race, Se_Foothill (July-August, 2001-2002), Gorevka Village, Komi Republic, Russia, NEKG (N $61.05^{\circ}$, E $\left.58.27^{\circ}\right)$ - 686, 790-792, 890, 893, 1063-1065, 1067, 1146, 1162-1166, 1225, 1229, 1314-1316, 1380-1386, 1399, 1401, 1403, 1405-1408, 1462-1464, 1466, 1467, 1547-1550, 1557, 1559, 1560, 1579, 1581, $1584,1586,2431,2541,2552,2571,2579,2612,2614,2678,2775,2776,2795,2802,2803,2826,2828,2829$, 2831-2833, 2881, 2927, 2929, 2956, 2962, 2965, 2966, 2976, 2992, 2997, 2999, 3000, 3001, 3002, 3009, 3031, $3053,3071,3072(n=89)$.

Serov Race, Se Hill (July-August, 1995, 2001), Jani Peak of Ural Mt., Komi Republic, Russia, NEKG (N $62.08^{\circ}, \mathrm{E} 59.08^{\circ}$ ) - 77, 80, 134, 135, 171, 189, 190, 261, 264-266, 283, 284, 288, 301, 302, 328, 329, 333, 334, $335,372,373,422,432,435,477,480,511-513,515,559,560,562-565,625,642-644,669-674,689,707,729$, $771,772,774,777,788,798,807,811,812,816,818,819,820,887,923-927,929-933,1015,1036,1044-1046$, $1061,1066,1070-1073,1923,1924,1944,2059,2061,2133,2365,2490,2802,2806(n=96)$.

Manturovo Race, Ma Ramen'e (July-August, 1980-1981), Ramen'e Village, Arkhangelsk Oblast, Russia, EEKG $\left(\mathrm{N} 61.00^{\circ}, \mathrm{E} 42.0 \overline{0}^{\circ}\right)-461,462,486,488,489,501,506,508,514,518,519,542,656,827,843,849$, $850,857,858,1027,1031,1084,1098,1144,1145,1150,1166,1189,1227,1239,1245,1297,1329,1336,1348$, 1386, 1436, 1446, 1472, 1480, 1484, 1564, 1576, 1577, 1612, 1623, 1710, 1771, 1834, 1841, 1859, 1920, 1927 , 2032, 1329a $(n=55)$.

Manturovo Race, Ma_Dan (July-August, 1987-1988), Dan' Village, Komi Republic, Russia, EEKG (N $61.38^{\circ}$, E $\left.51.80^{\circ}\right)-98,609,621-623,664,673,679,686,695,702,703,705,706,715,719,725,730,737,755$, $768-770,777,792,800,803,805,808,812,813,815,820-822,962,965,967,1015,1032,1037,1046,1054$, $1058,1064,1071,1073,1076,1078,1084,1086,1087,1098,1100,1101,1126,1131,1132,1149,1153,1156$, $1157,1162,1173,1181,1191,1192,1194,1209,1212,1216,1230,1235,1242,1245,1262,1399,1407,1408$, $1432,1440,1441,1450,1454,1456,1480,1482,1496,1503,1520,1559,1622,1627,1629,1655,737 \mathrm{a}, 815 \mathrm{a}$, 983a, 998a, 1078a, 1131a $(n=101)$.

Pechora Race, Pt Ulashevo (July-August, 1992), Ulashevo Village, Komi Republic, Russia, EEKG (N $65.42^{\circ}$, E 57.12 ${ }^{\circ}$ - 1001, 1002, 1007, 1009, 1011, 1012, 1017, 1018, 1019, 1021-24, 1026, 1027, 1030, 1032$1034,1037,1038,1041,1042,1046,1048,1049,1053,1055,1057,1059,1061-1065,1067,1070,1073,1076$, 1078-1084, 1088, 1092, 1093, 1095, 1096, 1101, 1102, 1104, 1105, 1113, 1120, 1122, 1127, 1134, 1142, 1145 , $1148,1149,1152,1153,1164,1165,1168,1173-1177,1181,1182,1185,1150 \mathrm{a}(n=78)$. 
Sok Race, So_Kokshaga (October, 2009), "Bolshaja Kokshaga" Nature Reserve, Mari El Republic, Russia,

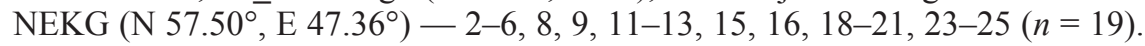

Sok Race, So_PuZla (July-August, 2009), Verhnaja Puzla Village, Komi Republic, Russia, NEKG (N 62.43, E $\left.54.65^{\circ}\right)-143,145,146,6261,6270-6273,6275,6279,6280-6282,6284-6288(n=18)$.

Sok Race, So_STorogevsk (July-August, 2009), Storogevsk Village, Komi Republic, Russia, NEKG (N $\left.61.94^{\circ}, \mathrm{E} 52.33^{\circ}\right)-6,7,9-13,23-35,48-51,62,63,65-69(n=31)$.

Sok Race, So_SLuda (July-August, 2009), Malaja Sluda Village, Komi Republic, Russia, NEKG (N 62.00, E $\left.50.38^{\circ}\right)-1,15-17,19,20,36,39,45-47,52-55,57,59-61,70,102,106-111,150,152,153,156-158,160-$ $162,21 \mathrm{a}, 21 \mathrm{~b}, 103 \mathrm{a}, 103 \mathrm{~b}, 104 \mathrm{a}, 104 \mathrm{~b}(n=42)$.

\section{APPENDIX 2}

Results of Tukey pair-wise comparisons on centroid size (* - significant after Bonferroni correction)

Table 1. Skull (lower diagonal) and mandible (upper diagonal)

\begin{tabular}{|l|c|c|c|c|c|c|c|c|c|c|}
\hline & Se_V & Se_F & Se_H & Ma_R & Ma_D & Pt_U & So_K & So_PZ & So_ST & So_SL \\
\hline Se_V & - & $8.882^{*}$ & $10.60^{*}$ & $6.125^{*}$ & 4.275 & $7.427^{*}$ & 0.803 & 3.216 & $8.255^{*}$ & $6.006^{*}$ \\
\hline Se_F & $10.49^{*}$ & - & 1.719 & $15.01^{*}$ & $13.16^{*}$ & $16.31^{*}$ & $9.685^{*}$ & $12.1^{*}$ & $17.14^{*}$ & $14.89^{*}$ \\
\hline Se_H & $12.32^{*}$ & 1.83 & - & $16.73^{*}$ & $14.88^{*}$ & $18.03^{*}$ & $11.4^{*}$ & $13.82^{*}$ & $18.86^{*}$ & $16.61^{*}$ \\
\hline Ma_R & $8.012^{*}$ & $18.5^{*}$ & $20.33^{*}$ & - & 1.85 & 1.302 & $5.321^{*}$ & 2.909 & 2.13 & 0.1183 \\
\hline Ma_D & 3.81 & $14.3^{*}$ & $16.13^{*}$ & 4.202 & - & 3.152 & 3.472 & 1.059 & 3.98 & 1.731 \\
\hline Pt_U & $6.769^{*}$ & $17.26^{*}$ & $19.09^{*}$ & 1.243 & 2.959 & - & $6.624^{*}$ & 4.211 & 0.8282 & 1.421 \\
\hline So_K & 3.742 & $14.23^{*}$ & $16.06^{*}$ & 4.27 & 0.069 & 3.027 & - & 2.413 & $7.452^{*}$ & $5.203^{*}$ \\
\hline So_PZ & 2.313 & $12.8^{*}$ & $14.63^{*}$ & $5.7^{*}$ & 1.498 & 4.457 & 1.429 & - & $5.039^{*}$ & 2.79 \\
\hline So_ST & $8.301^{*}$ & $18.79^{*}$ & $20.62^{*}$ & 0.289 & 4.491 & 1.532 & 4.56 & $5.989^{*}$ & - & 2.249 \\
\hline So_SL & $7.103^{*}$ & $17.59^{*}$ & $19.42^{*}$ & 0.910 & 3.292 & 0.333 & 3.361 & $4.79^{*}$ & 1.199 & - \\
\hline
\end{tabular}

Table 2. First lower molar $\mathrm{m} 1$

\begin{tabular}{|l|c|c|c|c|c|c|c|c|c|c|}
\hline & Se_V & Se_F & Se_H & Ma_R & Ma_D & Pt_U & So_K & So_PZ & So_ST & So_SL \\
\hline Se_V & - & $0.00015^{*}$ & $0.000149^{*}$ & $0.002528^{*}$ & 0.09885 & $0.00025^{*}$ & 0.9999 & 0.422 & $0.000158^{*}$ & $0.003265^{*}$ \\
\hline Se_F & & - & 0.9666 & $0.000149^{*}$ & $0.000149^{*}$ & $0.000149^{*}$ & $0.000149^{*}$ & $0.000149^{*}$ & $0.000149^{*}$ & $0.000149^{*}$ \\
\hline Se_H & & & - & $0.000149 *$ & $0.000149 *$ & $0.000149 *$ & $0.000149 *$ & $0.000149 *$ & $0.000149^{*}$ & $0.000149 *$ \\
\hline Ma_R & & & & - & 0.9476 & 0.9951 & $0.01399 *$ & 0.5646 & 0.8837 & 1 \\
\hline Ma_D & & & & & - & 0.4508 & 0.3157 & 0.999 & 0.1577 & 0.9651 \\
\hline Pt_U & & & & & & - & $0.000873^{*}$ & 0.1099 & 0.9999 & 0.9908 \\
\hline So_K & & & & & & & - & 0.7872 & $0.000244^{*}$ & $0.0178^{*}$ \\
\hline So_PZ & & & & & & & & - & $0.02467 *$ & 0.6208 \\
\hline So_ST & & & & & & & & & - & 0.847 \\
\hline So_SL & & & & & & & & & & - \\
\hline
\end{tabular}


APPENDIX 3

Hotelling's pair-wise comparisons with Bonferroni correction $(*-p<0.05 ; * *-p<0.01 ; * * *-p<0.001)$

Table 1. Skull (lower diagonal) and mandible (upper diagonal)

\begin{tabular}{|c|c|c|c|c|c|c|c|c|c|c|}
\hline & Se_V & Se_F & Se_H & Ma_R & Ma_D & Pt_U & So_K & So_PZ & So_ST & So_SL \\
\hline $\mathrm{Se}_{-} \mathrm{V}$ & - & $* * *$ & $* * *$ & $* * *$ & $* * *$ & $* * *$ & $* * *$ & n.s. & $* * *$ & $* * *$ \\
\hline $\mathrm{Se} \_\mathrm{F}$ & $* * *$ & - & $* * *$ & $* * *$ & $* * *$ & $* * *$ & $* * *$ & $* * *$ & $* * *$ & $* * *$ \\
\hline $\mathrm{Se} \_\mathrm{H}$ & $* * *$ & $* * *$ & - & $* * *$ & $* * *$ & $* * *$ & $* * *$ & $* * *$ & $* * *$ & $* * *$ \\
\hline Ma_R & $* * *$ & $* * *$ & $* * *$ & - & $* *$ & $* * *$ & $* * *$ & $* *$ & $* * *$ & $* * *$ \\
\hline Ma_D & $* * *$ & $* * *$ & $* * *$ & $* * *$ & - & $* * *$ & $* * *$ & n.s. & * & $*$ \\
\hline $\mathrm{Pt} \_\mathrm{U}$ & $* * *$ & $* * *$ & $* * *$ & $* * *$ & $* * *$ & - & $*$ & n.s. & * & n.s. \\
\hline So_K & $* * *$ & $* * *$ & $* * *$ & $* * *$ & $* * *$ & $* * *$ & - & n.s. & n.s. & $*$ \\
\hline So_PZ & $* * *$ & $* * *$ & $* * *$ & * & $* * *$ & $* * *$ & $*$ & - & n.s. & n.s. \\
\hline So_ST & $* * *$ & $* * *$ & $* * *$ & $* *$ & $* *$ & $* * *$ & n.s. & n.s. & - & n.s. \\
\hline So_SL & $* * *$ & $* * *$ & $* * *$ & $* *$ & $*$ & $* * *$ & n.s. & n.s. & n.s. & - \\
\hline
\end{tabular}

Table 2. First lower molar m1

\begin{tabular}{|c|c|c|c|c|c|c|c|c|c|c|}
\hline & $\mathrm{Se}_{-} \mathrm{V}$ & $\mathrm{Se} \_\mathrm{F}$ & Se_H & Ma_R & Ma_D & Pt_U & So_K & So_PZ & So_ST & So_SL \\
\hline $\mathrm{Se}$ V & - & $* * *$ & $* * *$ & $* * *$ & $* * *$ & $* * *$ & $* * *$ & $* * *$ & $* * *$ & $* * *$ \\
\hline Se F & & - & $* * *$ & $* * *$ & $* * *$ & $* * *$ & $* * *$ & $* * *$ & n.s. & $* * *$ \\
\hline $\mathrm{Se} \_\mathrm{H}$ & & & - & $* * *$ & $* * *$ & $* * *$ & $* * *$ & $* * *$ & $* * *$ & $* * *$ \\
\hline Ma_R & & & & - & $*$ & n.s. & $* * *$ & $* * *$ & $* * *$ & $* * *$ \\
\hline Ma_D & & & & & - & n.s. & $* * *$ & * & n.s. & * \\
\hline Pt_U & & & & & & - & $* * *$ & $* * *$ & $*$ & $* * *$ \\
\hline So_K & & & & & & & - & $* *$ & $* * *$ & $* * *$ \\
\hline So_PZ & & & & & & & & - & n.s. & n.s. \\
\hline So_ST & & & & & & & & & - & n.s. \\
\hline So_SL & & & & & & & & & & - \\
\hline
\end{tabular}

